\title{
HOBA 1СТОРIЯ
}

УДК 94 (477.7) «18» Лагус

DOI: https://doi.org/10.33782/2708-4116.2021.4.89

Ігор Сапожников

\section{В. ЛАГУС І ЙОГО ЛИСТИ ПРО ПОДОРОЖ 1851 РОКУ 3 ОДЕСИ ДО ОЛЬВІЇ ТА СЛІДАМИ АРМІЇ КАРЛА ХІІ}

«Стоишь тыл, призрак древней саги,

В своей столице над толпой

И вдохновенным взмахом шпаги,

Как прежде, манишь за собой».

В. Брюсов «Карл ХІІ пам'ятник у Стокгольмі»

Присвячується 200-річному ювілею професора Хельсінкського університету Вільгельма Лагуса

Анотація: У статті републіковані забуті «Листи з Чорного моря», присвячені опису подорожі 1851 року з Одеси до Ольвї. У ході неї були проведені археологічні розшуки та огляд місиь таборів шведської армії, яка після поразки під Полтавою відступала під проводом короля КарлаХІІ від Південного Богу до Бендер. Автором листів є Якоб Йохан Вільгельм Лагус (1821-1909) - доктор філософії, професор і ректор університету. Більшу частину життя він займався східним $i$ грецьким мовознавством, історією та нумізматикою Фінляндї, а після згаданої поїздки написав книгу «Карл ХІІ у Південній Росї̈ (останнє видання 2018 р.). У подорожі брали участь професори Рішельєвського ліщею, фахівиі з історичної географії П.В. Беккер і Ф.К. Брун.

У статті подана біографія В. Лагуса та його внесок у дослідження минулого Північно-Західного Причорномор'я. Особлива увага приділена поїзді, яку можна розглядати як одну з перших спроб проведення комплексної історико-археологічної експедищї у названому регіоні. Автор реконструював ї̈ маршрут і хронологію, звернувши особливу увагу на описи археологічних пам'яток і решток місць стоянок-таборів на шлхху шведських військ. Залучивщи відомі та неопубліковані карти, а також дані власних спостережень і розвідок, автор дійшов висновку, що датування В. Лагусом низки оглянутих земляних укріплень 1709 р. не підтвердилось: городище Петухівка II і два земляні укріплені табори Чортувате та Коблеве датуються римським часом. Прямокутний табір між Руською косою та гирлом б.Гетьманової шведи вірогідно використовували, оскільки там знайдені монети Швеції 1630-1650-х рр., але його треба віднайти та дослідити.

\footnotetext{
* Сапожников Ігор Вікторович - доктор історичних наук, провідний науковий співробітник Відділу Криму і Північно-Західного Причорномор'я Інституту археології Національної Академії наук України, член Національних спілок краєзнавців і журналістів України (Чорноморськ, Україна); ORCID: https://orcid.org/0000-0003-3889-6714; e-mail: ssappog5@gmail.com
} 
Ключові слова: В. Лагус, Північно-Західне Причорномор'я, Одеса, Ольвія, Карл ХІІ, шведський відступ, Руська коса, Волоська коса, Очаків, Тилігул, римські військові табори

Нещодавно мені вдалося ознайомитись 3 «Листами з берегів Чорного моря» 1851 року, які досі невідомі вітчизняним вченим ${ }^{1}$, хоча інша робота того ж автора давно входить до історіографії втечі військ Карла XII до Бендер у 1709 р. Йдеться про брошуру фіна Вільгельма Лагуса, написану на базі щоденників попутників шведського короля i спостереженнях, зроблених під час подорожей Північно-Західним Причорномор'ям². Проблема полягає в тому, що нерідко автором цієї книги вважають батька вченого, а коли авторство визначене вірно, то опублікований не його портрет (рис. 1), а фотознімок батька 3 . Саме тому в цій статті наведена біографія першого з них та описані його внесок до історії названого регіону і поїздка, під час якої були написані «Листи», які републікуються (Додаток).

Якоб Йохан Вільгельм Лагус (Jakob Johan Wilhelm Lagus; 5 травня 1821 p. - 3 квітня 1909 р.) народився у м. Або (Турку), у родині Вільгельма Габріеля Лагуса (25.07.178618.12.1859) - історика, професора i ректора Гельсінгфорського (Хельсінкського) університету. 1839 р. вступив до того ж закладу (закінчив у 1844 р.). Пізніше: доцент (1846), доктор філософії (1847), професор східних (1857) і грецької (1866) мов та ректор університету (1878-1884). у 1850-1854 pр. вчився та стажувався у Російській імперії, Туреччині, Греції, Італії й Австрії ${ }^{4}$ Міжнародне визнання отримав завдяки працям зі східної філології ${ }^{5}$ займався також історією та нумізматикою Фінляндії. Плутанина сина 3 батьком сталася тому, що вони були професорами і ректорами одного університету, а в їхніх складних іменах присутнє одне спільне. На землях колишньої Російської імперії відома книга В.Лагуса про Е.Лаксмана (1737-1796) - геолога і біолога, академіка Імператорської академії наук у Санкт-Петербурзі .

Тема Карла XII у Причорномор'ї підіймалася до В. Лагуса. На одній карті регіону 1775 р.

\footnotetext{
${ }^{1}$ Лагус [B., профессор]. Письма с берегов Черного моря. Санкт-Петербургские ведомости. 1851. № 270, 273, 277, 283-284; Лагус В. Письма с берегов Черного моря. Труды Я.К. Грота. Т. V: Деятельность литературная, педагогическая и общественная (1837-1889). Санкт-Петербург: Тип. МПС, 1903. С. 570-598.

${ }^{2}$ Лагус В. Карл ХІІ в Южной России. Одесса: Гор. тип., 1852. 34 с.; Лагус Ф. Карл ХІІ в Южной России // ЗООИД. 1853. Т. III. С. 306-337; Лагус В. Карл XII в Южной России. Карл ХII. Москва: Терра, 2018. С. 375-406.

${ }^{3}$ Forsen B. Monipuolinen tiedemies. Tieteessä tapahtuu. 2008. № 1. P. 32-33.

${ }^{4}$ Väisänen M. Lagus, Wilhelm (1821-1909). Kansallisbiografia 5, Helsinki, 2005. S. 675-677.

${ }^{5}$ Lagus J.J.W. Lärokurs i Arabiska Språket till Universitets-Ungdomens tjenst. 3 vols. Helsingfors, 1869-1878; Harviainen T. Wilhelm Lagus: A Pioneer of Cuneiform Research in Finland // Studia Orientalia Finnish Oriental Society. 2009. Vol. 106. P. 367-376.

${ }^{6}$ Karttunen K.J.J. W. Lagus: kirje Pietariin ja bibliografia // H. Halén (ed.), Samudraphena - valtameren vaahto: kirjoitelmia itäisiltä mailta professori Pentti Aallolle hänen 80-vuotispäivänään 22.VII.1997. Helsinki: Suomen Itämainen Seura, 1997. P. 57-77.

${ }^{7}$ Lagus Wilh. Erik Laxman, hans lefnad, resor, forskningar och brefvexling. Helsingfors: Finska Litteratursällskapets tryckeri, 1880. 498 p.; Лагус В. Эрик Лаксман, его жизнь, путешествия, исследования и переписка. Санкт-Петербург: Тип. Имп. АН, 1890. II, 488 с. У 1772-1773 pp. Е. Лаксман здійснив подорож «навколо усієї Молдови і Бесарабії, відвідавши Акерман, Бендери, Ізмаїл, Кілію, Яси та збираючи геологічні та біологічні зразки (Вказ. праця, с. 94-97).
} 
городище Баліклея у гирлі р. Чичеклеї на Бузі підписане «шведской замок» ${ }^{8} 1845$ року Н.І. Павлищев склав карту «Росія під час Петра Великого» 3 маршрутом шведських військ від Полтави до Бендер. За ним втікачі перейшли Буг вище гирла р. Інгул і пройшли далі пересипами лиманів (від Тилігульського до Хаджибейського), а потім степом до Бендер 9 . Розробку теми почав Ф.К. Брун статтею «Сліди табору Карла XII біля Бендер». Ї̈̈ головною метою була публікація двох планів околиць Бендер і с. Варниці, знятих у 1837-1838-х рр. Б.Я. Ейтнером на прохання ОТІС ${ }^{10}$. у ній був описаний шлях руху від Бугу до Очакова 3 двома зупинками ${ }^{11}$. Після цього у Ф.К. Бруна виникла ідея запросити до Одеси сина свого знайомого В. Лагуса, що володів шведською та мав доступ до щоденників супутників Карла XII та інших матеріалів. Це запрошення могло бути офіційним від ОTIC ${ }^{12}$, до складу якого В. Лагуса прийняли вже 1852 р. у віці 31 року ${ }^{13}$.

Молодший Лагус написав у «Листах», що через кілька днів після поїздки до Ольвії «відправився до Бессарабії, потім їздив до Дуная і, нарешті, у Варницю, місце табору біля Бендер» (Додаток, VII), причому в останньому місці був 28 липня ${ }^{14}$. Отже, вчений здійснив чотири поїздки з Одеси, про другу і третю з яких нічого невідомо. Оскільки підсумки четвертої поїздки описані ${ }^{15}$, зосередимо увагу на першій. Ї̈̈ можна датувати червнем - початком липня 1851 р. Супутниками були професори Рішельєвського ліцею Ф.К. Брун і П.В. Беккер кращі на той час фахівці з історичної географії Північно-Західного Причорномор'я.

Виїхавши з Одеси Миколаївським шляхом, подорожуючі зупинились на ніч на станції Сичавській. Наступна ночівля, після огляду околиць Коблеве (Троїцького), була в них біля Красного трактиру на ст. Сосицькій (с. Красне). Протягом третього дня, перепочивши у Янчокраці (Кам'янці), вчені доїхали до Парутина пізно ввечері. Наступний день вони провели на руїнах Ольвії, а п'ятий присвятили мандрівці на лівий берег Бугу, де оглянули район Руської коси та б. Гетьманової. На шостий день учасники подорожі, залишивши Парутино, побували у Миколаївці (Яселках), Куцурубі й Очакові, де заночували. 3 цього міста протягом сьомого дня вони досягнули Сичавки, звідки на восьмий день повернулись до Одеси (Додаток, IV).

Проілюструємо сказане топографічними картами. Шлях від Сосицької до Янчокраку відрізнявся від сучасного, оскільки йшов старим поштовим трактом через б. Кільчень (с. Калабатіно), Кам'яний міст (с. Суходол) і впритул Могили Розкопаної (рис. 6; Додаток). Теж саме слід сказати про дорогу від Очакова до Тилігулу, яка вела між морем і с. Ближній Бейкуш (Чорноморка) на перевіз через гирло Березанського лиману (рис. 8), справа повз

\footnotetext{
${ }^{8}$ Зберігалась у фонді № 388 «Російське географічне товариство» Ленінградської публічної бібліотеки (нині РНБ). Див.: Петрунь Ф.Е. Нове про татарську старовину Бозько-Дністрянського степу // Східний світ. 1928. № 6. C. 165.

${ }^{9}$ Павлищев Н. Исторический атлас России. Варшава: Тип. С. Стромбского, 1845. Карта XII.

${ }^{10}$ Брун Ф. Следы лагеря Карла ХІІ, возле Бендер, у селения Варницы // 300ИД. 1850. Т. ІІ. Отд. 2-3. С. 555. Табл. XVIII; Сапожников И., Левчук В. Исследования и описания места лагеря Карла XII в Варнице в 1810-х 1850-х гт. // Sava E., Ploşniţa E. (ed.). Situl istoric «Tabăra regelui Suediei Carol al XII-lea de la Varnița». Restaurarea memoriei. Chișinău: Muzeul Național de Istorie a Moldovei, 2017. P. 46-48, 53, pис. 1.

${ }^{11}$ Брун Ф. Вказ. праця. С. 556-557.

${ }^{12}$ Сапожников И., Левчук В. Вказ. праця. С. 50.

${ }^{13}$ Лагус Ф. Карл ХІІ в Южной России... С. 306-307.

${ }^{14}$ Ibid. C. 326.

${ }^{15}$ Ibid. C. 325-329; Сапожников И., Левчук В. Вказ. праця. С. 50-51.
} 
с. Аджіяськ ${ }^{16}$ (Рибаківка) і далі вздовж берега Чорного моря (рис. 4$)^{17}$. В. Лагус повідомив, що на зворотному шляху вони «проїхали Тилігульским пересипом вздовж самого моря, тоді як у перший проїз трималися ближче до лиману» (Додаток, VII) і це цілком зрозуміло, бо дорога 3 Аджіяська виходила на берег лиману значно південніше с. Коблеве. На картах кінця 1840-х - початку 1850-х років поштова Миколаївська дорога в районі станції та трактиру Сичавських пролягала значно ближче до берега моря, про що свідчать і графічні матеріали. Саме по ній в обох напрямках рухалась фура з вченими, але у зворотній бік частково (рис. 2-4). Пізніше шлях перенесли північніше на 2,4-2,8 км, майже на трасу сучасної дороги (рис. 5), що внесло певну плутанину у прив'язки відкритих місць знахідок у 1836, 1839 рр. римських кам'яних плит з написами й інших пам'яток ${ }^{18}$ (рис. 2).

За В. Лагусом, подорож мала на меті: перше - пошуки залишків існування давніх народів, друге - «прослідкувати шлях, яким пройшов північний Олександр [Македонський] (Карл XII) після своєї поразки» (Додаток, I). Зрозуміло, що археологічну частину виконували переважно П.В. Беккер і Ф.К. Брун. Зауважу, що у 1851 р. найвідоміша праця П.В. Беккера «Берег Понта Евксинського від Істра до Борисфену» була завершена, хоча й не надрукована повністю ${ }^{19}$. Ф.К. Брун, як і П.В. Беккер, бував в Ольвії до 1851 р., а також ще не менше двох разів. Він доволі детально описав останні візити, але жодного разу прямо не згадав експедицію 1851 року ${ }^{20}$.

На жаль, В. Лагус у «Листах» навів про археологічні дослідження небагато фактів. По суті вони зводяться до розвідок в околицях Коблеве, Руської коси, сс. Аджигол і Куцуруб. Однак їх провели переважно у пошуках залишків таборів військ Карла XII i тому ми розглянемо їх далі. Окремо скажемо про огляд В. Лагусом «величезного кургану» біля Анчокрака напевне незадовго до того пограбованої Розкопаної Могили, а також про спільну екскурсію на руїни Ольвії, під час якої були виконані заміри могил-катакомб (кам'яних склепів). Вчені побачили там наслідки масових пограбувань археологічних пам'яток: «На кожному пагорбі видно сліди лопат; деякі нібито кротами пориті, бо в усіх напрямках поколоті щупами». Автор порівняв це явище з «різновидом землеробства», який, на його думку, не приносить користі «систематичним дослідженням» і заборонений власниками помість цього району» (Додаток, IV).

Втім, наведені тим же В. Лагусом факти свідчать, що у Парутиному і навколо існувала стала система пошуків і збуту більш-менш коштовних артефактів, до якої були залучені якщо не самі землевласники, то їх представники. Найщінніші та габаритні знахідки

\footnotetext{
${ }^{16}$ В. Лагус назвав його Аджіян (Додаток VII; Прим. I.C.)

${ }^{17}$ Традиційнішою була переправа через лиман у районі с. Коза - Лимани (рис. 8).

${ }^{18}$ Мурзакевич H. О двух эллинских надписях, найденных вблизи Троицкого, в имении полковника Кобле // ЗООИД. 1844. Т. І. С. 277-283; Уваров А. Исследования о древностях Южной России и берегов Черного моря. Вып. 2. Санкт-Петербург: Тип. экспед. изготовл. гос. бумаг, 1856. С. 144.

${ }^{19}$ Беккер П. Берег Понта Эвксинского от Истра до Борисфена, в отношении к древним его колониям. Одесса: в Гор. тип., 1851. 61 с.; Becker P. Die Gestade des Pontus Euxinus vom Ister bis Borysthenes in Bezug auf die im Altertume dort gelegenen Kolonien. Mémoires de la Société Impériale d’archéologie: 1851. Bd. V. S. 361-387; 1852. Bd. VI. S. 103-138, 176-193; Беккер П.В. Берег Понта Эвксинского от Истра до Борисфена, в отношении к его древним колониям // З0ОИД. 1853. Т. III. С. 196-203.

${ }^{20}$ Брун Ф. Донесение о поездке к устьям рек Буга и Днепра, в 1862 году // 300ИД. 1863. Т. V. С. 985-993, табл. 4-5; Аркас Н., Брун Ф. Археологическая разведка некоторой части Ольвии // 300ИД. 1872. T. VIII. С. 412414, табл. Х; Сапожников И.В., Кашуба М.Т. Из истории создания «Древностей Геродотовой Скифии»: сотрудничество ИАК с Ф.К. Бруном в 1860-х гг. АВ. 2021. (у друці).
} 
зберігалися у маєтках, де гості могли їх оглядати. На ганку будинку управляючого в с. Анчокрак стояли два парні мармурові леви, які тепер в Ермітажі ${ }^{21}$. Пізніше Ф.К. Брун повідомив, що у 1862 р. хотів перевірити точність знятих ним кілька років тому малюнків (тамговидних знаків) на левах, але скульптури вже відправили до Санкт-Петербургу «для розміщення їх у новобудованому будинку власника помістя». Він же сказав, що леви були знайдені в «одному з ольвійських курганів» ${ }^{22}$, але В. Лагус зазначив, що це був «Великий» або Зевсів курган на агорі, а леви знаходились «при подошве этого кургана, под самой поверхностью земли». Він згадав і про те, що П.В. Беккер визначив у цьому маєтку дві рідкісні монети. Крім того, 3 «Листів» видно, що торгівля знахідками копачів йшла не тільки в Парутиному, але й в Очакові і самі вчені не цуралися їх придбання (Додаток, IV) для власних колекцій і музею ОТІС.

Що стосується матеріальних свідчень походу Карла XII, то від лівого берега Бузького до Тилігульського лиману Ф.К. Брун і В. Лагус локалізували п'ять із семи зупинок військ з 4 до 15 (17) липня 1709 р., оскільки ще дві мали місце під час обходу з півночі БерезанськоСасицького лиману ${ }^{23}$.

Руська Коса. Ф.К. Брун першим відзначив тут рештки фортифікації: «В этом месте, лежащем напротив развалин Ольвии и принадлежащих к имению Свято-Троицкое, поныне видны следы земляных укреплений, сделанных шведами» ${ }^{24}$. В. Лагус додав, що «земляний окоп» знаходиться дещо на південь від Руської Коси і «сліди цього окопу ще видні на огрядному пшеничному полі» (Додаток, V). Раніше він повідомив, що Карл XII наказав обвести цей табір земляними валами, а запорожці стали нижче коси в гирлі б.Гетьманської, а на місці шведського табору він побачив: «Вали бачимо тут серед хлібних полів біля Бугу, який маючи тут ширину принаймні 6 верств, нерідко тече бурхливими хвилями. Берег від площини поля майже прямовисно схилився до води. Степ тут непомітно скатистий в обидва боки так, що табір залишається на найвищому місці». Тут після дощів знаходили «шведские, польские и турецкие монеты» ${ }^{25}$. На кургані біля б. Гетманової були помічені явні «прикмети риття скарбів» ${ }^{26}$. Сказане нібито підтверджує «триверстова карта» початку 1850-х років, на якій у 2,0-2,1 км на південний схід від тодішньої стрілки коси, на березі подвійними лініями позначений прямокутник. Він розташований лише за 300-400 м на північ від гирла б. Гетьманової (рис. 7) і більше відповідає опису місця табору запорожців, де козаки «зараз обкопалися» ${ }^{27}$. Цікаву інформацію про цю місцевість знаходимо на планах А.П. Чиркова, знятих у 1863 р. на замовлення ОТІС. Йдеться про зображення с. Федорівки з Руською косою з уточненням «місце переправи шведського короля Карла ХІІ» і околиць с. Кисляківки ${ }^{28}$. На першому у

\footnotetext{
${ }^{21}$ Мурзакевич Н. Ольвийские древности // ЗООИД. 1853. Т. III. С. 247. Табл. VI, I-II; Соломоник Э.И. Сарматские знаки Северного Причерноморья. Киев: Изд-во АН УССР, 1959. С. 87-97.

${ }_{22}^{22}$ Брун Ф. Донесение... С. 993.

${ }^{23}$ Лагус Ф.Вказ. праця. С. 322-323; Додаток VI. Зауважу, що у цих роботах хронологія руху шведів відрізняється на два дні.

${ }^{24}$ Брун Ф. Следы лагеря... С. 556.

${ }^{25}$ Зберігались у музеї ОТІС, більша частина яких належала до часів королеви Христини (1630-1650-х рр.). Лагус Ф. Вказ. праця. С. 318, 333.

${ }^{26}$ Лагус Ф. Вказ. праця. С. 317-319.

${ }^{27}$ Томашівський С. Із записок Каролинців про 1708-9 р. // ЗНТШ. 1909. Т. 92. С. 88.

${ }^{28}$ Сапожников И.В. Картографические материалы по археологии, истории и географии низовий Буга и Днепра: работы А.П. Чиркова 1863-1866 годов. Історія. Етнографія. Культура. Нові дослідження. Миколаїв: Атол, 2000. С. 259-261. № 7-8.
} 
вказаному місці на краю уривчастого берега позначений не підписаний прямокутник розмірами близько 180×100 м (рис. 9). На другому плані також присутня нижня частина б. Гетьманової, але залишки козацького табору відсутні (рис. 10) ${ }^{29}$.

Волоську косу названі автори визнавали шведською стоянкою апріорі, не описуючи їх слідів. А.П. Чирков уточнив, що це «місце висадки при переправі шведського короля» ${ }^{30}$. В. Лагус написав, що мав намір оглянути неподалік Чортів (Чортуватий) яр і «рештки давнього укріплення», але почало сутеніти (Додаток, VI). На плані А.П. Чиркова наявні два значні кургани (один - Волошанська Могила) і дві артилерійські батареї часів Східної війни, але урочище Чортувате виходить за його межі (рис.10). Однак, такий обєєк є на картітриверстівці 1850-х рр. між гілками яруги, справа від дороги в с. Козирку як квадрат зі сторонами 70-80 м. 3 1810-х рр. низка авторів вважала цю споруду римською. Але його прив'язка В.І. Назарчука і С.Б. Буйських (на лівому березі лівого відгалуження Чортуватого яру) $)^{31}$, не відповідає топографічній карті (рис. 7).

«Становище Кантемірове» за 5 верст [5,33 км] вище Очакова» визначив як шведський табір Ф.К. Брун ${ }^{32}$. Судячи 3 його прив'язки та опису (Додаток, VI), перед нами відоме городище римського часу Петухівка II, розташоване на березі Дніпро-Бузького лиману між с. Дмитрівка та гирлом р. Аджигол. Хоча пам'ятка неодноразово досліджувалась шляхом розкопок, дані про шведські знахідки відсутні ${ }^{33}$.

Табір Куцуруб В. Лагус побачив як: «чотири низенькі земляні вали, які утворюють майже квадрат у 80 кроків [56,9 км], зі входами в середині кожного боку. Місцями земля розкопана: видно, що тут в пізніші часи шукали залишків старовини. Можна припускати, що у цьому чотирикутнику був розбитий «Царський намет», коли шведи 13-15 липня останній раз стояли табором біля Очакова» (Додаток, VI). У наш час на східній околиці і в західній частині села відомі три поселення 3 матеріалами античного та елліністичного часу, але вали на них не зафіксовані ${ }^{34}$, як не видно нічого подібного і на старих картах (рис. 8).

Табір Коблеве описаний В. Лагусом: «Ще досі видно у Коблевці або Троїцькому, на схід від Тилігулу за 1늘 версти від сільської церкви, поблизу одного великого кургану квадратний шанець із земляними валами завдовжки близько 70 кроків [49,8 м] і заввишки до 1 сажня [2,13 м]»35. У «Листах» він згаданий двічі, але інакше: висота названа меншою - 1,42 м, довжина також 48,8 м, але йдеться про вхід з одного кута (Додаток, III, VII). Скоріше за все, попутники не вбачали в обєкті шведського табору, бо жодного разу про нього не згадали. В.Лагус написав, що «дійсно мали привал 16 [3 14 на 15] липня. Може вали оточували простір з багатим наметом короля, бо відомо, що Карл, де б він не знаходився, любив захищати себе якимось

\footnotetext{
${ }^{29}$ Ближче до Кисляківки на березі розташована «колишня батарея», яка вочевидь була влаштована під час Східної (Кримської війни) у 1854-1855 рр.

${ }^{30}$ Сапожников И.В. Вказ. праця. С. 260.

${ }^{31}$ Буйских С.Б. Фортификация Ольвийского государства (первые века новой эры). Киев: Наук. думка, 1991. С. 58-59. Рис. 23.

${ }^{32}$ Брун Ф. Следы лагеря... С. 556. Це перше використання цієї назви до даної місцевості. В. Лагус повідомив, що термін Кантемір-юрт (кочів'я Кантеміра) зустрічається у «східних письменників», але за межами регіону: Лагус Ф. Вказ. праця. С. 322.

${ }_{33}^{33}$ Буйских С.Б. Вказ. праця. С. 50-55. Рис. 20 та ін.

${ }^{34}$ Гребенников В.Б., Каражей О.М., Яценко С.М. Пам'ятники археології Очаківського району (каталог довідник). Миколаїв: Іліон, 2011. С. 30-31.

${ }^{35}$ Лагус Ф. Вказ. праця. С. 336.
} 
укріпленням, і що він зазвичай посилав вперед людей для обладнання табору» (Додаток, VII). Цьому твердженню без посилання суперечить щоденниковий запис попутника короля Д. Крмана від 26 червня (7липня) 1709 р.: «королівський табір ані тут, ані деінде не був підперезаний ровом» ${ }^{36}$.

Можливо, через несприйняття Ф.К. Бруна і П.В. Беккера це укріплення було забуте та не потрапило до зводів археологічних пам'яток ${ }^{37}$. Однак воно не загубилось, бо ще у 1848 р. було нанесено на план, опублікований в альбомі ілюстрацій експедиції О.С. Уварова (рис. 2), а за кілька років - на «триверстову карту» (рис. 4-5). Оскільки в тексті про об'єкт не йдеться ${ }^{39}$, його відкривачем можна вважати топографа, унтер-офіцера А. Олексієва ${ }^{40}$. За його вимірами прямокутне укріплення з ровом і двома входами на довгих сторонах розташовувалося на схід від значного кургану, мало розміри по зовнішньому краю рову $95,7 \times 82,5$ м і було орієнтоване віссю майже суворо за лінією схід - захід. На тому ж плані літерою $\boldsymbol{a}$ позначене місце знахідки двох згаданих раніше мармурових плит, що були виявлені випадково на поселенні римського часу (рис. 2), яке інтерпретується як Одіссос.

На аерофотознімку інтернет-програми «Гугл-карти» об’єкт видно на винограднику як прямокутник світло-жовтуватого кольору із закругленими кутами розмірами 75×73 м по контуру, усередині якого є темніший квадрат $48 \times 47$ м. За 150 м на захід від нього стоїть нерозораний курган діаметром до 51-53 м , на якому в середині видне заглиблення та кільцева, овальна у плані виїмка діаметром 33-27 м. Обидві пам'ятки розташовані за 0,91,1 км на захід від південної околиці с. Коблеве на краю плато висотою близько +41 м, прилеглого до лівого берега Тилігульського лиману, в 1,4-1,5 км на південь - південний схід від православного храму села.

У травні 2021 р. автор оглянув обидві пам'ятки. Курган висотою до 4,8 м пограбований по центру яма 4,5×2,5 м і глибиною до 2,0 м, причому її викид частково засипав північнозахідну частину кільцевого рову; на схилах $є$ інші покопи та сміття. Рів, викопаний приблизно посередині висоти кургану, має ширину 1,5 м. Укріплений табір знищений оранкою, а рештки валу висотою 0,3-0,4 м видно на східному краю. Майже на всій площі об’єкту розмірами 70-71×69-70 м зустрічаються середні та дрібні уламки амфор (переважно червоноглиняних), їх концентрація помічена на сході - південному сході ділянки. Діагностичні фрагменти репрезентовані типами: Зеєст 72 і 75, CIb (у червоноглиняному виконанні) та Сia або СинІІІ (за Внуковим). Загалом комплекс знахідок можна датувати

\footnotetext{
${ }^{36}$ Крман Д. Подорожний щоденник (Itinerarium 1708-1709). Київ: Вид-во ім. О. Теліги, 1999. С. 90.

${ }^{37}$ Буйских С.Б., Иевлев М.М. Археологическая карта Тилигульского лимана // В.П. Ванчугов (отв. ред.). Древности Причерноморских степей. Киев: Наукова думка, 1993. С. 114-122.

38 Уваров А. Собрание карт и рисунков к «Исследованиям о древностях Южной России и берегов Черного моря» / Гравюры с натуры М. Вебель, сост. И. Медведев. [Санкт-Петербург], 1853. л. XXVII.

39 Уваров А. Исследования о древностях Южной России и берегов Черного моря. Вып. 2. Санкт-Петербург: Тип. экспед. изготовл. гос. бумаг, 1856. С. 143-144.

${ }^{40}$ Тункина И.В. Русская наука о классических древностях юга России: XVIII - середина XIX вв. СанктПетербург: Наука, 2002. С. 249.

${ }^{41}$ Офіщійно зафіксований лише у 1987 р. (з висотою 5 м, діаметром 60 м), але без будь-яких конструктивних особливостей: Гребенников В.Б., Бродецький О.О., Яценко С.М. Пам'ятки археології Березанського району (каталог-довідник). Миколаїв: ФОП Нігреєв М.А., 2010. С. 31
} 
двома хронологічними епізодами: серединою - другою половиною I та серединою II початку III ст. ${ }^{42}$

Не виключено, що в указані періоди переобладнаний курган разом 3 табором функціонували як єдиний спостережно-оборонний комплекс біля ще не виявленого поселення і так званої дороги Варварів з Ольвії у бік Тіри ${ }^{43}$. На користь такого висновку свідчить свідчення А.О. Скальковського, який у 1861 р. дорогою до Ольвії бачив «високі кургани з явними ознаками того, що це були передові сторожові укріплення» ${ }^{44}$.

Таким чином, підбиваючи підсумки огляду нерухомих матеріальних залишків походу шведів 1709 року, зазначимо, що відповідні дані про табір у с. Куцуруб відсутні, городище Петухівка II і ще два квадратні земляні укріплення - табори (Чортувате і Коблеве) датуються римським часом, останній переважно I-II ст. від РX. Прямокутний табір між Руською косою і гирлом б. Гетьманової шведи, виходячи зі знахідок монет 1630-1650-х рр., вірогідно, використовували, але це слід перевірити на місцевості або підтвердити невідомими раніше картографічними матеріалами.

У цілому ж, републікація такого цінного історичного джерела як «Листи» В. Лагуса, в якому міститься й інша, нерозглянута нами інформація, значно розширює джерельну базу досліджень Ольвії та їі округи у середині XIX ст., до якої вже увійшли аналогічні, хоча й популярніші нариси I.I. Кедрина, А.О. Скальковского й ін. ${ }^{45}$ Для увічнення пам'яті їх автора не буде перебільшенням назвати ім'ям цього фінського вченого описаний ним курган біля Коблеве.

Подяки: автор виказує щиру вдячність С.С. Аргатюку за бібліографічні консультації та О.С. Сінельнікову за визначення керамічних матеріалів.

\section{Додаток}

\section{ПИСЬМА С БЕРЕГОВ ЧЕРНОГО МОРЯ}

\section{I}

Возвратясь недавно из поездки по Херсонской губернии, я намерен начать обещанные мной заметки рассказом о прогулке моей по этой части степного пространства южной России, столь замечательного во многих отношениях: здесь совершились некогда важные события, но над ними мрак забвения часто спорит со светом истории, и только в наше время просвещение, под покровом могущественнейшей державы, озарило этот отдаленный край Европы своими благотворными лучами.

Еще не так давно грозный полумесяц скрылся в волнах перед Очаковом и Измаилом, и светлый меч Карла XII помрачился под Полтавой; вдали пылает багровое как кровь полуночное солнце

\footnotetext{
${ }^{42}$ Внуков С.Ю. Причерноморские амфоры І в. до н.э. - ІІ в. н.э. (морфология). Москва: Институт археологии РАН, 2003. С. 52-54, 145; Внуков С.Ю. Причерноморские амфоры І в. до н.э. - ІІ в. н.э. (петрография, хронология, проблемы торговли). Санкт-Петербург: Алетейя. 2006. С. 168, рис. 10.

${ }^{43}$ Сапожников И.В., Синельников А.С. О римских земляных линейных укреплениях и дороге Варваров близ Ольвии // Нємченко І.В. (ред.). Стародавнє Причорномор'я. Вип. ХІІІ. Одеса: ОНУ ім. I.І. Мечникова, 2021. C. 381-392.

${ }^{44}$ Скальковский А. Поездка в Ольвию // ТОСК. 1870. Вып. IV. С. 110.

${ }^{45}$ Сапожников И., Аргатюк С. Иван Кедрин и его экспедиция 1850 года по Северо-Западному Причерноморью // Південний захід. Одесика. 2018. Вип. 24. С. 9-39; Скальковский А. Поездка в Ольвию... C. 102-112.
} 
Золотой Орды, а за ним - будто пары, подымающиеся из пропасти - мелькают тени народов с именем и без имени, которые с исхода IV века сменялись один за другим, уничтожая с дикою жаждою истребления все, что ни встречалось им.

Вот насколько мы должны удалиться назад, чтобы на этом театре ужаснейших переворотов увидеть более приятные и мирные /571/ явления; хотя и они исчезли невозвратно, но как все, что однажды приняло жизнь и образ от творческой силы греческой культуры, они навсегда принадлежат к прекраснейшим воспоминаниям человечества. Двадцать столетий протекло после падения столь счастливых некогда греческих колоний, которые процветали по берегам Черного моря; но мне все-таки хотелось взглянуть на природу и места, посреди которых они жили и отжили, мне хотелось посмотреть, не найду ли хоть каких-нибудь остатков их давнего существования - и я пустился в степи. Другой целью моей было проследить путь, которым шел северный Александр (Карл ХІІ) после своего поражения.

Прежде всего должен я сказать, что я сделал эту поездку в самом приятном и поучительном обществе, - с профессорами Ришельевского лицея: Ф.К. Бруном и П.В. Беккером, которые с живой любовью к археологии соединяют самый общительный и милый характер; первый из них родом финляндец. Четвертое место в нашем экипаже не было занято, но в мыслях мы единодушно отдавали его, с дружеским воспоминанием, нашему соотечественнику, профессору А.Д. Нордману, который недавно из этих краев переселился в родную Финляндию и посвятил свою плодотворную деятельность тамошнему университету. Как мы жалели, что его не было с нами, для объяснения красноречивых надписей в раскрытой под майским небом книге природы!

Мы были очень довольны фурманом и экипажем, который наняли в Одессе на всю поездку. Этим способом едва ли не всего беззаботнее и спокойнее можно ездить по России, по крайней мере в таких случаях, когда не хочешь зависеть от неуклонного направления большой дороги. Но не всякому выбор так хорошо удается, как нам. Правда, что экипаж длиною более двух сажен [>4 м], сам по себе принадлежал к роду скрипучих, а висевшая с боку на железной цепи жестянка еще усиливала стукотню, так что нам трудно было разговаривать, но зато мы сидели на сене как на pecсорах. Наши россинанты, увешанные бубенчиками, конечно, не выиграли бы нам на скачке 1го, 2-го или даже 3-го приза, но соединенными силами дюжины ног они все-таки пробегали условленные 40-60 верст [42,7-64,0 км] в день. А тот маленький, кругленький человек, что сидел у нас на козлах? и его не надобно забывать: меня долго занимал вопрос, к какой нации он принадлежал.

Он родился и жил в Бессарабии, но не был русским: для него были почти совершенно чужды русские нравы, религия и язык. Он также не был «швабом», хотя его вообще и называли так, распространяя это областное имя на всех колонистов, которых /572/ предки переселились сюда из Германии. Столько же мало шло к нему более почетное название немец, так как надобно быть по крайней мере полугосподином, чтобы в южной России заслужить это имя. Но если бы даже и забыть всякое различие состояний, - боюсь, что этот простак скоро обмолвился бы перед диалектическим судом языкознания. Он был очень прост, но честен и добродушен, - в этом надобно отдать ему справедливость, хотя вслед затем нельзя не прибавить, что из всех душевных качеств, в самой меньшей доле досталась ему храбрость. Но виноват ли он, если ему в степи мерещились страшные привидения? Напротив, я готов видеть только доказательство особенной откровенности в том, что он при малейшем обстоятельстве, которое пробуждало его трусость, оборачивался к нам с плачевной физиономией и жалобно произносил: «ich habe Angst» [я боюсь (нем.)]. Таков был наш шваб, и он, конечно, не пустился бы с нами по неведомым для него дорогам, если бы не чувствовал какого-то родственного к нам влечения, узнав, что одного из нас зовут Вильгельмом - «точь в точь как его сына в лавке на Старом базаре [в Одессе]».

Мы оставили за собой заставу, препятствующую вывозу товаров порто-франко. Вместе с тем очутились мы вне предместья и скоро миновали первый лиман, называемый Одесским или 
Малым Куяльником. «Пересыпи и лиманы» составляют два самые характеристические рода урочищ на северных берегах Черного моря. Пересыпями называются полосы земли, нанесенной двумя встречными массами воды, как здесь реками с севера и морем с юга. Иногда эти пересыпи еще не образуют одного цельного пространства, давая морю и реке сообщаться более или менее глубокими отверстиями, иногда же составляют они сплошную землю, поросшую травой и тростником: иногда они шириной только в несколько аршин, иногда в несколько верст, какова, например, та, по которой мы теперь тащимся, и в южном углу которой построено предместье Одессы, по имени ее и названное. Высота их вообще незначительна, так что по временам, от бурь или от напора сдерживаемой реки, они то отчасти, то вполне заливаются водой. $<. .>^{46}$

Пока меня занимали эти размышления, взошла луна - и вот она с задумчивой улыбкой озирает землю и воды. Здесь сияние ее не ослабляют светлые ночи, которых не знают на юге.

\section{II}

Миновав и Большой Куяльник, в нескольких верстах от Одессы, мы пустились по возвышенной степи прямо на восток и близехонько от нас справа тянулся дикий, изрытый берег Черного моря. Высоту этого побережья над поверхностью моря можно без преувеличения полагать в 80-100 футов; упоминаю об этом для того, чтобы вы не представляли себе здешнего края низменностью. Земля здесь не понижается постепенно (за исключением общего наклона поверхности), но оканчивается у моря крутым обрывом и как бы стеной, образующей террасу. Здесь нет твердого оплота скал и гор и оттого происходят беспрерывные изменения берега; вот почему и можно извинить древних, если их описания уже не согласны с действительностью, если расстояния в их периплах часто определены неверно. Но о древних и говорить нечего: стоит только сравнить лучшие карты нашего времени (одна из новейших Манганари), и мы увидим, что не одни человеческие познания идут вперед, но и сама природа не стоит неподвижно.

В отношении упомянутого берега можно представить себе море в беспрерывной наступательной войне с твердой землей. При/574/ каждом ветре волны ударяются о берег с ужасной силой; может быть напор их останется безуспешным сегодня и завтра, но они беспрестанно возвращаются с новою яростью и наконец разгром удается им. Подрыто единственное твердое основание берега, конгломерат из улиток и извести, называемый здесь камнем и который в целой южной России составляет третий или четвертый слой земли. Пограничная линия степи, постоянно атакуемая морем, колеблется, уступает, рушится - и волны с торжеством прорываются через нее $<. . .{ }^{47} / 576 /$

Не всегда отличаются точностью известия греков даже о тех местах, которые сами они заводили для торговых и других выгод на берегах моря и впадающих в него рек. Как ни увеличивается в наше время народонаселение степи, она все еще малолюдна, а иногда, на пространстве целых миль даже необитаема; поэтому можно судить, как скудно была она населена в древности. Не надобно увлекаться длинным списком имен древних селений; число их было во всяком случае не так велико, по отношению к огромному пространству края, и притом самые селения были по большей части ничтожны. Только немногие пункты возвысились торговлей, и служа общими, обыкновенно укрепленными складочными местами менового торга, были более известны. Прочие селения надобно считать только промежуточными станциями или привалами для мореходов. Они быстро возникали и также быстро рушились или переносимы были на другия места, так как существование их зависело столько же от приязни своих, сколько и от вражды чужих. Вот отчего в периплах и других не менее обширных описаниях упоминается то одно, то другое селение и редко встречаются одни и те же в течение долгого времени. По большей части от

\footnotetext{
${ }^{46}$ Вилучений фрагмент про походження слова «лиман». - I.C.

${ }^{47}$ Вилучений фрагмент про абразію узбережжя та зміни рівня моря. - I.C.
} 
них не остается ничего, кроме имени, и мы тщетно стараемся определить их место на наших картах.

Но читатель, конечно, найдет, что мы подвигаемся уж слишком медленно и мы сами сознаемся в том. Скоро уже полночь, а мы добрались только до Дофиновки, первой станции от Одессы. Маленькая остановка очень порадовала нашего фурмана, который с истинно отеческой нежностью берег своих лошадей.

По мнению полковника Стемпковского, который с наибольшей точностью занимался исследованием греческих колоний между Днестром и Днепром, - на этом месте находился древний Скопелос. Здесь есть пресная вода и протекает речка Малый Куяльник или Аджилык (в настоящее время только лиман), а к стороне моря земля образует возвышенность, которая могла послужить поводом к древнему названию места. Но мнение г. Стемпковского основывается на ошибочном предположении, будто римской мили соответствует русская верста. Притом из земли не вырыто (в течение 26 лет) ничего, чтобы подтвердило догадку его. Не будем и мы терять времени на копание, тем более, что в таких незначительных местах, каким во всех отношениях был Скопелос, случаю чаще, нежели /577/ предвидению ученых удается, как говорит народ, найти на свое счастье денежек.

Пока лошади лакомились овсом, я слушал довольно оригинальный деревенский концерт, который производили две скрипки и кимвал; музыканты были польские жиды и это мне объяснило, каким образом два или три танца их по такту и мелодии походили на те польки, которые мы слыхивали на севере.

Дорога от Дофиновки далее сохраняет тот же характер, но он выражается тем более резкими чертами, чем расстояние от Одессы увеличивается: там, поблизости города, человеческий ум сделал несколько попыток против однообразия природы. С трех сторон степь, с четвертой море, кое-где долины, в которых реки или речки давно уже пересохли, кое-где обрыв, нигде ни горы, ни скалы, ни даже порядочного камня, нигде ни леса, ни рощи, ни даже хоть дерева или куста, за исключением разве посаженных как на страже перед домами более зажиточных людей. Для нас, жителей гористой Финляндии, непонятно, как у степи могут быть также свои поэты, как и этот «бедный край» может тронуть сердце и воодушевить лиру. Но действительно и здесь поются песни, и здесь живет поэзия.

В 8 верстах [8,5 км] от Дофиновки, по четвертой пересыпи (считая от Одессы), проехали мы мимо четвертого лимана, называемого Большим Куяльником; проехав еще 8 верст, прибыли мы в деревню Сычевку [Сычавку], которая лежит при небольшой, летом пересыхающей речке. Не только в русских городах, но и по дорогам встречаются так называемые «постоялые дворы» с меблированными комнатами для проезжих. Не редко можно получить прислугу, съестных припасов мало, а постельного белья нельзя достать даже и в самых лучших гостиницах. Иметь с собою все нужное в дороге и затруднительно и дорого. Для семейных путешественников это легко: они-то и ввели этот порядок вещей, возя с собой запасы съестного и другие принадлежности дороги, часто даже постели, кухонную посуду и уголья. Но что наверное можно найти везде, даже и в последней избе, - это самовар, который несомненно доказывает вам, что вы в России.

\section{III}

На следующее утро, не позже как часа через два после восхождения солнца, мы находились уже на развалинах древнего Одесса. Правда, Данвиль (d'Anvile) и все его последователи полагают, что этот город находился на месте нынешнего Очакова; по мнению некоторых ученых при дворе Екатерины II, он был там, /578/ где ей основана Одесса; в самом же деле чуть ли не на середине между этими двумя пунктами. Бларамберг, сколько я помню, первый высказал догадку, что древний Одесс лежал в 45 верстах к востоку от нынешней Одессы и в 2 верстах к югу от деревни и 
почтовой станции Коблевки или Троицкой ${ }^{48}$. Эта догадка впоследствии принята и другими. г. Стемпковский достиг того же результата сравнением расстояний по исчислению древних. г. Мурзакевич не только соглашается с этим мнением, но из двух найденных близ Коблевки в 1837 и 1839 годах греческих надписей выводит самые смелые заключения о благосостоянии и значительности города в древности ${ }^{49}$.

Подле самого города протекала река Aхіaces; русло ее теперь занимает обширный соленый и рыбистый лиман Телигульский с его широкой пересыпью, в которой от 4 до 5 верст ширины и которая известна под именем плавней. В иные годы покрывающий ее тростник вырастает в сажень [2,15 м] вышины и служит тогда убежищем волкам (единственному роду хищных зверей в степи), но мы видели один голый пустырь, поросший низкой ползущею зеленью, где местами являлись небольшие озера, иногда соединявшиеся узенькими протоками с лиманом или морем.

Так как для гавани, которую Арриан нашел здесь еще во времена Плиния, по свойству местности не остается иного пункта, кроме самой пересыпи, то здесь можно, кажется, отчасти решить вопрос: к какому именно времени относится происхождение этого рода приморских урочищ? Безименный плаватель по Черному морю, который явно имел в виду исправить и пополнить прежние показания, особливо Арриановы, говорит об Одессе, но уже вовсе не упоминает о гавани. Итак уничтожение гавани и образование пересыпи надобно отнести к IV-му столетию [от РХ].

В Коблевке обратились мы к управителю, от которого, как живущего здесь постоянно, можно было ожидать точных местных сведений. Сам он был в отлучке, но сын его надел сапоги и отправился с нами в поле. Солнце палило немилосердно, а в душе мы сгорали жаром любознательности. Да и какой антикварий не воспламенился бы от рассказов такого красноречивого проводника о находках, сделанных и здесь, и тут, и там? Он бывал за границей, может быть даже в Париже, но, по-видимому, кроме коллекции родной деревни, никакие другие не имели для него цены. /579/

Из его слов можно было заключить, что вся Коблевка - музей; что в каждой куче сору отыскано здесь какое-нибудь великое сокровище. На такой классической земле все приобретало для меня высшее значение; воображением переносился я в другие времена, усердно писал под диктовку в мою дорожную тетрадь, набивал себе карманы обломками камней, отмечал совестливо места, где они лежали, и терпеливо нес весь этот груз в знойное утро. Но прогулка была так продолжительна, что ревность моя уже начала остывать; я думал: нашему молодцу надобно разгуляться, он болтает еще в просонках, мы разбудили его слишком рано. Я выбросил самые тяжелые из моих приобретений. Мы продолжали идти; вот место (у столба 2-й версты), где выкопаны упомянутыя две надписи. Наш ментор считал фундамент какой-то лачужки памятником древности. Я еще облегчил свои карманы. Но красноречие нашего чичероне шло все выше и выше, вместе с солнцем; он рассказывал нам о древних могилах с уцелевшими остовами, о монетах, обломках стрел, глиняных сосудах, урнах, вазах и т.д. Жаль только, что он забыл, кому они достались; место, где находились эти драгоценности, уходило от нас, как Рифейские горы, все дальше и дальше, по мере того, как мы подвигались. Решено было позавтракать и потом воротиться верхом или в экипаже.

Подкрепив свои силы, я нетерпеливо ожидал, когда мы опять пустимся в путь. «Сейчас, сейчас, сию минуту!» Между тем наш оратор не знал, как бы отделаться от нас. Уже он более не мог служить нам проводником, у него дома не было лошадей, в нашем экипаже он бы только стеснил нас; но он на лоскутке бумаги начертил воображаемые курганы; они, по словам его, были у самой дороги, - стоило только ехать все прямо и т.д.

\footnotetext{
${ }^{48}$ Не Телигульский ли? См: Российский почтовый дорожник. СПб., 1842, № 1099. (Прим. В.Л.).

${ }^{49}$ Вероятно, эти надписи принадлежали Ольвии, потому что на них нет имени города (Прим. перекл.).
} 
После всего этого легко представить себе, как охотно я принял последний совет. В Коблевке я уже довольно наслышался о древнем Одессе, хотя, за исключением разве самой местности, не видел ничего интересного в археологическом отношении. Но я должен заметить мимоходом, что мы во время прогулки нашей, в некотором отдалении на восток от церкви села и к северу от предполагаемого места города, завидели курган, который, будучи самым большим в целом околотке, привлек наше внимание. Подойдя к нему, мы вымеряли находящееся вблизи почти квадратное земляное укрепление с валом, вышиной аршина в два [1,42 м] и длиной около 160 футов [48,8 м]. Трава была здесь гуще и свежее, нежели в прочих местах, но предания молчали. Воображение наше разыгралось на свободе; из всех возможных догадок мне более всего нравилась мысль, что этот вал насыпан шведами во время похода Карла XII. Но об этом после. /580/

Нужно ли мне говорить, что нам так же мало, как Дарию, посчастливилось достигнуть скифских могил, к которым мы стремились? Но ежели есть хоть какая-нибудь доля правды в том, что я с недоверием слышал, то, надеюсь, что оно все-таки не будет потеряно для науки, так как молодой граф Уваров совершил по этому краю путешествие с археологическою целью и, вероятно, вскоре издаст о нем большое сочинение.

Мы ехали почтовым трактом, который от Телигульского лимана идет на северо-восток и таким образом все более удаляется от морского берега, и прибыли в Сасицкую [станцию] или Красный трактир. Это - расстояние длинное и пустынное; таковы, конечно, сибирские тундры и степи Аравии, если только вместо травы и цветов предположить мох и песок. Однако же здесь путешественнику есть чем занять свои мысли, при виде множества курганов или могил, которые, как острова, разбросаны по ровной и плоской почве. Они созданы не природою, хотя можно спросить, откуда же взята земля для сооружения их, когда в окрестностях не видать никаких углублений или ям? К тому же они существуют с незапамятных времен. <... ${ }^{50} / 581 /$

Станция Красный трактир ничем не оправдывает своего заманчивого имени. Здесь нет даже порядочной воды для питья. Серая, мутная влага медленно протекающей речки Сасика хоть и не совсем засохла, но ею поят только скот. В колодцах, как обыкновенно, мы нашли соленую жесткую воду, а цистерны были пусты. У нас в Финляндии, обильной ключами, жажда только в крайности утоляется дождевой водой, а здесь это из всех напитков самый здоровый и лучший; особливо хороша эта вода при кипячении, и потому превосходна для чая.

\section{IV}

Проехав в ужасный зной еще 16 верст [17,1 км], мы очутились на мосту над речкой Березань, которая чуть текла под нами ручейком сажени на две ширины $[4,3$ м]; в илистой воде ее купались дети и телята. Далеко расходящиеся берега ее и вся окрестность показывают, однако же, что река эта некогда была гораздо значительнее. От того не без основания полагают, что она уже была известна древним под именем Rhode (у Плиния), если только оно не принадлежало скорее Сасику или его лиману, который, огибая оконечность выступающего клином полуострова, сливается с лиманом Березани (Овидиев Sagaris?). Оба эти лимана почти одинакового размера, имея верст 1213 в длину [12,8-13,9 км] и 3-4 версты [3,2-4,3 км] в самом широком месте. Теми же цифрами означается их совокупное течение, которое, образуя залив Березанский (Плиниев sinus Sagarius?), изливается в море, а не отделяется от него пересыпью, как все доселе названные лиманы.

Объехав эти воды, мы направились к юго-востоку в Янчокрак (27 верст [28,8 км] от Красного трактира), поместье графа Кушелева-Безбородько, /582/ с тенистым садом на небольшом притоке Березани. Здесь жена управляющего приняла нас радушно и угостила кофеем, превосходно испеченным теплым хлебом и свежим сливочным маслом. Мы с часок роскошничали на

\footnotetext{
${ }^{50}$ Вилучені поетичні міркування щодо курганів. - І.C.
} 
старинных диванах, в простых, но просторных и прохладных покоях, и потом осмотрели, какие здесь есть остатки древности.

Их оказалось не слишком много: несколько монет, в числе которых профессор Беккер нашел две очень редкие, бюсты и два мраморные льва. Но эти вещи отрыты не в Янчокраке (хотя разрытый огромный курган, который я посетил, чтобы в разрезе рассмотреть его устройство доказывает, что и здесь народное поверье мечтает о кладах); эти вещи перевезены сюда из Ольвии. Львы, украшающие крыльцо управляющего, принадлежат к числу замечательнейших предметов, найденных в земле, хотя до сих пор еще никем не описаны. Они из белого мрамора, натуральной величины и, за исключением морды, вполне уцелели. Оба совершенно сходные между собой, они лежат с приподнятой головой, опущенным хвостом и протянутыми вперед лапами; у каждого в боку находится выточенное углубление диаметром в 4 дюйма [10,2 см], где укреплен был конец соединявшего их мраморного цилиндра (которого теперь уже нет). Стиль резца, кажется мне, может быть отнесен не далее, как за два века до Р.Х.; пропорции неверны, и второстепенные части отделаны не тщательно. Кожу образуют какие-то иероглифические фигуры, несколько похожие и на монограммы ольвийских монет и на руническое письмо.

Уже смеркалось, когда мы выехали из Янчокрака; так как до Ольвии еще оставалось верст 2025, то мы взяли с собой проводника, молодого крестьянина. Любо было смотреть, как он гарцевал на своем коне; он сидел молодецки, как отличнейший кавалерист, глаз у него был соколиный; как «сын степи», он был вскормлен на коне; он родился всадником - казак в полном смысле.

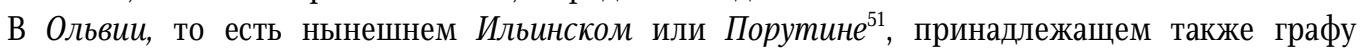
Кушелеву-Безбородько, мы провели вечер и часть ночи, просматривая небольшую, но отборную коллекцию монет и других собранных на месте древностей, составленную управляющим имения, молодым бароном Р., нашим любезным и гостеприимным хозяином. На следующий день уже рано утром в целом околотке знали о нашем приезде; все, кто только промышлял открытием древностей /583/ (мужчины, женщины, дети), собрались толпой на дворе, предлагая древние монеты, ручки разбитых сосудов (diotae), под названием астиномов, лампы, слезники, чаши и другие изделия, обломки мрамора, иногда с остатками какой-нибудь надписи и пр. Мы, однако же, до времени устранились от этого пестрого базара антиков и поспешили отправиться к самым развалинам, лежащим в версте $\left[1,01\right.$ км] с небольшим к югу от Порутинской церкви. $<\ldots>^{52} / 584 /$

Развалины Ольвии лежат при небольшом заливе, образуемом косами Волошской и Сарыколек $^{53}$, на возвышенном западном берегу ${ }^{54}$ Буга, о котором древние часто упоминают под именем Гипаниса (Hypanis). Следы города занимают едва $1 \frac{1}{2}$ квадратной версты, но при этом две большие земляные насыпи, в которых еще при Бларамберге легко было узнать остатки башен (Catetor и Posius), и площадь Ста могил остаются далеко за пределами города. Окрестность гористая; обращенные к реке долины сменяются /585/ возвышенностями, и можно бы подумать, что дома обрушились вследствие землетрясения или одного из тех обвалов, которые так обыкновенны в южной России, если бы только не было известно, что в самых углублениях не отрыто ничего значительного. Самое большое из них называется нынче «Городская балка», отделяя пространство, где, как думают, была крепость или акрополь (на севере), от самого «города» (на юге), как называется в народе место, где открыто всего более древностей.

\footnotetext{
${ }^{51}$ Не слышится ли в этом имени искаженное название Борисфена или Борусфена, которое Ольвия также носила в древности? (Прим. В.Л.).

52 Вилучений популярний та застарілий нарис історії Ольвії.

53 За верность этих двух названий не можем ручаться, так как они в подлиннике написаны только латинскими буквами (Прим. В.Л.).

${ }^{54}$ Укерт, Кольстер и др. говорят: на восточном - непонятная ошибка. Кто бы принял это показание при исследовании расстояний по Периплам и другим источникам, тот не далеко ушел бы (Прим. В.Л.).
} 
На каждом пригорке видны следы лопат; иной как-будто изрыт кротами, так он во всех направлениях исколот щупами. Разумеется, что для пользы науки и систематических исследований, этот род земледелия запрещен владельцем имения или имений; но что делать, если тайная богиня «случая» неприметно передаст что-нибудь бобылю или работнику? Все вещицы, которыя мы после приобрели или осматривали, появились на свет этим невинным образом.

Вид из Ольвии величественный, но пустынный. Взойдем на так называемый «Большой курган», на котором, вероятно, стоял храм Юпитера, место, куда сходились жители Ольвии для совещаний, где они слушали и речь Дия, дошедшую до нас с другими его сочинениями; при подошве этого кургана, под самой поверхностью земли, найдены львы, осмотренные нами в Янчокраке; - или взойдем на Акрополь, лежащий в немногих только шагах от Большого кургана, ниже по течению реки. Перед нами лиман Буга (уже верст в 10 шириной [10,7 км], хотя до воронкообразного устья его остается еще 12-15 верст [12,8-16,0 км]), часто, как и в эту минуту, оживляемый рыбачьими лодками, пароходами, военными кораблями и другими судами, идущими в Николаев или из этого города, который отсюда не далее как в 30 верстах к северу. На противоположном, также крутом и как будто только что обвалившемся берегу реки, степь расстилает опять свою зеленую скатерть, в складках которой кое-где мелькает то деревня, то сельская церковь; на синеющем юго-востоке она оканчивается мысом Станислава (у древних Hippoleon с храмом Цереры), под которым сливаются волны Буга и Днепра и вместе продолжают течение с востока на запад под именем Днепровского лимана. Крестьяне уверяют, что в совершенно ясное утро виднеется по другую сторону этого залива длинная и узкая Кинбурнская коса, единственное на значительном расстоянии место, где растут деревья в диком виде и которое у древних поэтому называлось Нуlаса (лесным). Со стороны твердой земли окрестности Ольвии, по своей природе, разделяют общий характер степи. Стоит, однако же, упомянуть о бесчисленных, еще во времена Дия существовавших здесь курганах, которые стоят рядами один возле другого и сообщили пространству к юго-востоку от развалин название «Сто могил»./586/ Множество колодцев, плодоносные поля, луга и огороды свидетельствуют более о трудолюбии, нежели о превосходстве грунта.

В заключение мы посетили и вымеряли задолго перед сим открытые и очищенные катакомбы или могильные склепы. Эти памятники составляют приятное явление здесь, посреди уединенной природы и жаль было бы уничтожать их. Меня немало удивило, что они так хорошо сохранились, хотя построены (как, без сомнения, вообще здешние жилища и в старину и ныне) из мягкого известняка, легко уступающего обыкновенной пиле и топору. Но это, конечно, было преимуществом в их подземной архитектуре. Замечательно устройство крыши: она состоит из выдающихся уступами одна над другой плит, которых выказывающийся край обшлифован и образует род весьма твердого свода.

Назад мы отправились водой, держась берега как можно ближе. Мы знали, что искатели монет с большим успехом промывают землю, которая из «города» или Акрополиса скатывается в реку. Но, к сожалению, дул юго-восточный ветер и волны с яростью ударялись о берега. Чтобы вознаградить себя за эту неудачу, мы набили себе все карманы гончарными изделиями, которыми здесь наполнена земля. Обилие их заставляет предполагать, что здесь некогда находилась фабрика, - догадка, которая подкрепляется глинистым свойством здешней почвы (по берегу, к северу от Акрополиса) и нисколько не опровергается тем, что знаменитые вазы из Эгины и Корциры составляли и в Ольвии важную статью привоза.

Как я сказал, на дворе того дома, где мы остановились, нанесено было множество древностей. Особенно живо шел меновой торг монетой, потом сбыт всяких ручек и других обломков и мелочей; всего хуже продавались мраморные изделия, потому что их мы не могли взять с собой, хотя между ними многое стоило бы того. Замечательнее всего в этом роде был еще не описанный четырехугольный пьедестал, который я и срисовал с позволения управляющего (пьедестал хранится у него). Это прекрасный мраморный камень длиной в 17 вершков [76,5 см], шириной в 13 
[58,5 cм], а высотой вершков в 9 [40,5 см]; на верхней стороне его находятся углубления для ног статуи, и на нижней, против самого того места, где приходятся пятки, две круглые впадины диаметром в 4 дюйма [10,2 см]. Лицевая сторона так повреждена, что из десяти еще остающихся строк надписи, впрочем весьма явственной, можно прочесть только последние четыре. «Народ приносит свою благодарность Юпитеру-хранителю, который содействием одного согражданина даровал ему благодеяния победы ${ }^{55}$. Этого согражданина почтили статуей, подарком $1.000 / 587 /$ золотых монет и торжественным провозглашением награды на играх Диониса в театре». Что может быть прекраснее таких чувств? Но, отлагая всякие комментарии до более удобного случая, я прибавлю только, что на дворе, где живет староста, лежит мраморная доска, видом и величиной подобная предыдущей, с такими же выточенными на изнанке полушариями, но без надписи. Там же вделана в ограду каменная ваза грубой работы, вышиной около полуаршина.

\section{V}

Теперь переправимся через Буг, и, оставив древних, скажем несколько слов о делах более близкого к нам поколения. Но прежде бросим прощальный взгляд на прекрасный мраморный отрубок колонны, к которой привязана наша лодка, выпив стакан самой светлой воды в честь престарелого «отца истории», за его верное описание «горького» Гипаниса - и пусть теперь ветер, веющий над его волнами, поет в снастях и парусах. Всех нас на лодке 13 человек, но я думаю, никто из нас не суеверен; к тому же ведь мы сейчас причалим к «Гетмановой Балке», то есть к долине гетмана. Этот гетман - Мазепа <... ${ }^{56} / 587 /$ Не думайте, что я только повторяю слова какого-нибудь из строгих судей несчастного короля. Все, что я из книг могу теперь сообщить о его бегстве, заключается в «Voyages» современника Мотрея (Motraye), в записках тафельдекера Гультмана (Hultman), введенных «во время вседневного нахождения при особе покойного короля» и имеющих цену как выражение народного мнениями наконец в русской статье о лагере в Бендерах, написанной профессором Бруном. Остальное почерпну я из источников другого рода: природы и преданий. Но я не скрою, что всякое воспоминание казалось бы мне прекраснее, если бы оно относилось к бегству.

Не надобно также думать, будто я, как гость русских, смотрю /588/ на это дело их глазами: сами русские отзываются о Карле с похвальным беспристрастием и редко вы услышите недоброе слово о подвигах побежденного героя, хотя и казалось бы, что тесно стоять рядом двум таким национальным личностям, каковы Петр I и Карл XII.

Даже простой народ знает про победу царя, как самое блистательное событие отечественной истории в давнее время, но знает и много изумительных сказаний о пораженном короле. Вслушиваясь в местные предания, я нашел, что народному чутью так же мало, как и пытливости ученых, удалось решить в пользу Карла вопрос: какая побудительная причина, какая необходимость могла заставить его, в продолжение пяти тягостных для Швеции годов, медлить вдали от своего государства, от своей родины, от храброго народа своего, оставаясь в Турции, куда он спасся бегством? $<\ldots{ }^{57}$

5 июля шведы, после шестидневного пути, достигли восточного берега Буга, в том самом месте (принадлежащем к селу Свято-Троицкому), где мы теперь находимся. Лодок не было - они не могли переправиться. Поэтому они сделали земляной окоп несколько к югу от «Русской Косы»так называется мыс, всех далее выдающийся в Буг: следы этого окопа еще видны на тучном пшеничном поле. Здесь найдены шведские и польские монеты, доставленные одному собирателю в Одессе. Для таких находок роют землю, когда она размягчена дождем. Место это открытое и вид

\footnotetext{
${ }^{55}$ Слово «(К)allinniкот» могло быть собственным именем (Прим. В.Л.).

${ }^{56}$ Вилучені епічні порівняння Карла XII з Олександром Македонським.

${ }^{57}$ Вилучений фрагмент про труднощі, від яких потерпали шведські вояки.
} 
отсюда такой же, как из Ольвии, лежащей напротив, только немного южнее. Берег образует стремнину.

Мазепа с запорожцами стал лагерем с полверсты ниже по течению реки, где напоминают о нем упомянутая долина (Гетманова Балка) и огромный курган в ее углублении. $<. .>^{58} / 589 /$

Не прежде как 8 числа янычары в большой турецкой лодке перевезли короля на другой берег. Вслед за ним переправились епископ Мальмберг с 7 пасторами и Мазепа со своими казаками. Только спустя несколько минут после этого показалась русская погоня. Между оставшимися по эту сторону реки распространились ужас и беспорядок. 300 шведов были затоптаны в Буг и потонули, 500 человек были взяты в плен и уведены назад в Полтаву.

Печальна была переправа шведов через Буг в «Татарскую степь» (где скоро мы с ними опять сойдемся); теперь едва не случилось беды с нами. Но надобно уметь отличать опасность от действительного несчастия. Поэтому; хоть небо и покрывается тучами, мы можем спокойно пообедать у милой и веселой госпожи А. У нее богатый запас исторических воспоминаний о старом и новом времени, и она не откажет поделиться ими с путешественником, который дорожит такими сведениями. Узнав о нашей любознательности, предупредительная хозяйка позаботилась, чтобы само угощение ее было, по возможности, поучительным. Осетр, стерлядь, кефаль, судак и другие большие и малые представители влажного царства, служили для нас самыми верными оригиналами эмблем, всего чаще встречаемых на монетах Ольвии и других черноморских городов. Они намекали нам также на старинный, и поныне еще обильный источник продовольствия в здешнем крае. Не далее как за несколько недель тому назад, в Буге наловлено было столько рыбы, что с одной тоны получено ее на 90 возов, которые хозяйка и отправила в Одессу на базар: «90 chariots! que dites-vous, de grâce? est-ce possible, madame?» - «Quatre vingt-dix! je vous assure, chacun traîné par une paire de boeufs, et pourtant quantité de poissons s'étaient échappés par un trou du filet» ${ }^{59}$.

После того становится понятным /590/ как Кёлер, сколько ни был он учен, мог написать целую книгу об истории рыбной ловли в Черном море и реках, в него впадающих. 0, если бы все древности могли жить и размножаться таким же образом!

\section{VI}

В Свято-Троицком достигли мы самого восточного пункта нашей поездки и намеревались - не считая некоторых небольших уклонений в сторону - возвратиться в Одессу кратчайшим путем, то есть через Очаков. Когда мы вторично переправлялись через Буг, между пассажирами обнаружилось какое-то беспокойство, смущение, которое наш колонист лучше всех умел бы назвать, если бы он был с нами. Я с досадой заметил, что во время нашего отсутствия гребцы перевезли нашу лодку на полторы версты ниже. Они уверяли, что от «Русской Косы» и расстояние менее и течение сильнее. Но они не сообразили, что, если ветер хоть сколько-нибудь усилится, то труднее будет бороться с волнами, тогда как от места, где мы пристали, можно было как раз переплыть на другой берег. Я хотел сделать опыт и, объяснив им дело, просил, чтобы мне дали сесть у руля. Но так называемый штурман отвечал очень простодушно, что, конечно, я буду править так же плохо, как говорю (то есть по-русски). Итак, я остался на прежнем месте; вскоре опасность еще увеличилась.

На карте виден мыс над самой Ольвией, немного к северу, наискосок от «Русской Косы» или Свято-Троицкого. Мы стремимся к его оконечности; волны страшно качают нашу утлую, ветхую лодку, будто гороховый стручок; весла у нас - какие-то палки с привязанными на конце

\footnotetext{
${ }^{58}$ Вилучені несуттеві подробиці.

59 «90 телег! Скажите, пожалуйста, сударыня? Возможно ли это? - «Девяносто! Уверяю вас, каждый [конец невода] тащила пара волов, и все же много рыбы ускользнуло через дыру в сети». - I.C.
} 
дощечками, и потому служат очень плохо: с бакборда они едва достигают воды, а на противоположной стороне изломалось несколько пар. Штурман шумел и кричал, а взапуски с ним кричали и шумели все лодочники. Без всякой надобности поднялся такой гвалт, какого я никогда не слыхивал и на море. Когда мы достигли более мелкого места, моряки наши прибегли к помощи двух багров - детская попытка! Несколько часов мы бились около рокового мыса, который как дракон извергал на нас буруны; пристать было невозможно. Наконец решено плыть по ветру в залив, который далеко вдавался в берег; однакож гребцы не посмели поворотить лодку и мы должны были плыть задом, пока не смогли причалить. По этому примеру можно судить, как плохо знакомы со своею стихией рыбаки в реках южной России. Посадите же их на лошадь, и вы не налюбуетесь их ловкостью и проворством в безбрежной степи. /591/

За эту переправу наши гребцы взяли с нас дорого, да и в самом деле, им было много труда. Но всего неприятнее было то, что мы потеряли много времени. Нам оставалось еще версты две до порутинского дома, а когда мы дошли туда, было уже поздно и нам пришлось отложить до другого дня поездку в Чортову балку [овраг Чертов - рис. 7]. Мне хотелось побывать в этом месте (в 5 верстах к северу от Порутина), где Паллас видел остатки старинного укрепления ${ }^{60}$. Несмотря на ночное время, страшное название не могло бы испугать нас, потому что поводом к происхождению его послужило самое невинное обстоятельство: в этом месте находимы были монеты с изображением рогатой головы Пана, которую суеверие народное объяснило по своему.

В наше отсутствие один из соседних помещиков присылал звать нас к себе, предлагая взглянуть на некоторые древние надписи в его имении. Вот еще доказательство, что и в степи живет гостеприимство. Между тем мы при лунном свете бродили по Порутину, отыскивая копателей, которые сами не догадались явиться. Профессор Беккер купил у них несколько ценных монет.

Сколько я ни расспрашивал, мне не удалось услышать здесь никакого предания о Карле. Я желал узнать, где он пристал на этом берегу, где разбил палатку, в которой принимал пашу, поспешившего лично представиться высокому гостю и предложить ему лучший дом в Очакове; где стоял Гюлленшерна, когда он передавал отказ своего короля и с укоризной указывал на противоположный берег, где русский генерал еще продолжал истребление шведов. Как бы хотелось мне включить Ольвию в историю Севера! Никакой отголосок предания не дает мне на то права, и однако же для того, кто видел местность, так вероятно, что шведы переправились либо к самым развалинам, либо очень близко от них. Не найдется ли о том намека у какого-нибудь из спутников короля, или его тафельдекера, если внимательно пересмотреть их бумаги! В дневнике последнего сказано только, что «Его величество 10 июля приказал выступить от реки Великого Буга и Очакова и идти в Татарскую степь» - заметка, которая сама по себе уже требует пояснения. Под Очаковом Гультман, конечно, разумел не город (который лежит в 30 верстах слишком на запад от Буга), а восточный край области его; название «Татарская степь» он также употребил преждевременно, так как эта степь, по-видимому, начиналась только там, где, по ту сторону Березани, прекращалось Турецко-Очаковское наместничество [sic]. Но от несчастного, который бежит с поля битвы, нельзя требовать такой точности, тем более, что он видел одну степь, и даже ученым, которые могут трудиться в/592/ покое, еще не удалось явственно провести черту, отделявшую турецкие земли от владений татар, подвластных им только по имени. Из сказанного видно однако же, что когда шведы, оставив место, где был их лагерь, достигли противоположного берега, то они здесь дня два опять отдыхали и потом уже пустились далее. Мы вскоре вновь отыщем следы их и уже в дружественном для них крае.

Приятно было, при утренней прохладе, ехать в Николаевку - так называлось имение, откуда

${ }^{60}$ Останне твердження В. Лагуса не відповідає дійсності. - I.C. 
мы получили приглашение ${ }^{61}$ - и столько же приятно провели мы там время. С особенным удовольствием увидел я вдруг в столовой на стене Альденховенову прекрасную карту новой Греции, чего никак не мог ожидать, не зная, что семейство, у которого мы были в гостях, было родом из этой страны. Между народонаселением южной России много греков; одни поселились там уже с давних лет, другие - в новейшее время, и я возвращусь к ним в другой раз. Теперь поговорим опять о их предках.

Упомянутые надписи были на мраморе и лежали на дворе. Не без досады узнали мы, что они уже помещены в Бёковом (A. Boeckh) «Corpus Inscriptionum» под 2067 и $298^{62}$ : мы надеялись было найти что-нибудь совершенно новое. Уж эти мне ученые: обо всем надо им посудить! Берлинский профессор берется писать о двух каменных обломках «іn deserto Oczacoviano» [в пустыне Очаковской]. Сюда перевезли их конечно из Ольвии турецкие любители мрамора, для украшения своих бакчей. Но если мы в этом отношении и обманулись, все-таки я мог оставить Ольвию с одним новым взглядом.

Под этим я не то разумею, что любуясь со стороны моря видом, которому так много жизни придают суда, плавающие между Херсоном, Николаевым, Одессой и другими гаванями, я мог собственными глазами увериться в истине показания древних о лежащем напротив лесистом мысе «Hylaе»: он тянется с запада на восток от самой Кинбурнской крепости, которая вдали виднеется серой точкой. Об этом я еще прежде читал и теперь слышал в Ольвии. Но у меня родилась мысль, которую я и отдаю на суд вам.

Известно, в какое затруднение древние географы поставили новейших своих братьев некоторым противоречием касательно двух главных рек здешнего края: Буга (Hypanis) и Днепра (Вогуsthenes), помещая первую то на восток, то на запад от последней. Это показалось столь странным известному русскому археологу, г. [Н.И.] Надеждину, что он, для приведения дела в ясность, принял такое предположение: под Гипанисом должно разуметь не Буг, а Телигул, а под Борисфеном - не Днепр, а Березань и Буг. Если какой-нибудь /593/ древний автор, как например, Скимн или Дий, слишком упорно противится такому перемещению, то им не надобно верить, потому что первый - поэт, а второй - ритор. При этом совершенно упущено из виду, что для решения вопроса недовольно перенести предмет его несколькими верстами далее к западу. Но дело поясняется очень просто, если только согласно с действительным местоположением отвечать на вопросы, которая из обеих рек находится более на восток? Если смотреть на устья, то конечно Буг; но если иметь в виду самое течение обеих рек, то столь же несомненно - Днепр. Итак, в сущности, нет никакого противоречия в показаниях древних: надобно только уметь понимать их.

В древности утверждали, что под мысом Нурpolai, который мы вдалеке видели из Ольвии, обе реки впадают в одно «мелкое озеро», как говорить Геродот. Но другие считали это озеро продолжением Борисфена, как главной реки, которая таким образом изливалась в море не прежде, как под крепостью Алектора. Совершенно то же самое видим мы на нынешних морских картах, на которых широкий Днепровский лиман с западной стороны прекращается между Очаковым и оконечностью Кинбурна.

В Николаевке, так же как и в Ольвии, ничего не могли мне сказать о шведах, хотя, вероятно, они проходили здесь или, по крайней мере, в близком отсюда расстоянии. Кто читал, какое внимание они везде обращали на себя, - как турки и татары, привлекаемые любопытством или корыстью, сбегались толпами, чтобы увидеть бегущих или продать им провиант, тот не может не удивляться такому безмолвию преданий. Но оно становится понятным, когда сообразим, что для

\footnotetext{
${ }^{61}$ y 1830-х рр. земельна дача «Аджиголь, село с деревнями греков Федора и Николая Ивановых детей Качалиевых...» мала загальну площу майже 15 тис. десятин (РДАДА. Ф. 1354. Оп. 580. Ч. 1).

${ }^{62}$ Boeckhius A. (Ed.) Corpus inscriptionum graecarum. Auctoritate et impensis Academiae Litterarum Regiae Borussicae. Bd. 1-4. Berolini, 1825-1859. - I.C.
} 
исторических воспоминаний нужна местность, хоть в каком-нибудь отношении замечательная; что, напротив места, где проходили шведы, были повсюду однообразны, дики и в частности не отличались даже особенными названиями и что наконец впоследствии все прежнее население их удалилось, уступив место другому. Только этим объясняется замеченное нами забвение, ибо известно, что Карл, отказавшись от приглашения паши в Очаков, остался более недели вблизи города. Кроме означенного уже лагеря на западном берегу Буга, упоминается еще об одном далее «в степи» и о третьем, на расстоянии одного только часа от Очакова.

К месту второго лагеря, следы которого я искал в Николаевке, шведы прибыли 10 июля вечером. Король пробыл здесь несколько дней и велел написать отсюда латинское письмо к султану; уведомляя его о своем несчастии при Полтаве и вступлении в пределы Оттоманской Порты, он просил убежища для себя и всех бывших при нем, а также предлагал союз между Швецией, Польшей и Турцией против России. Таково содержание напечатанного у /594/ Мотрея письма, но в нем Карл не жалуется на поведение паши, как думали, кажется, сопровождавшие его шведы. Ко всему этому предание не прибавляет ровно ничего. Но дайте памяти народной точку опоры в каком-нибудь явственном урочище или создании человека, и воспоминание будет жить наперекор последующим событиям. Вот тому доказательство.

Когда король 13 числа отправился далее, его на пути встретили послы от самого султана. Бывший с Карлом при полтавском деле ага тотчас после сражения поспешил в Константинополь. В одно время с ним явился там русский гонец с известием, что шведский король либо убит, либо взят в плен. Но Ахмед, по-видимому, не терял надежды, и она вскоре оправдалась как эстафетом от Очаковского паши, так и письмом от короля, которое привез Нигебауер. Поэтому послы султановы ехали с поручением просить Карла в турецкие владения и поднести ему, сверх других подарков, великолепную палатку.

Мы знали, что о последнем подарке в народе сохранилась память. Когда, года два тому назад профессор Брун, приготовляя означенную статью, собирал сведения о так называемом в восточных известиях «Кантемировом месте», где был лагерь Карла, то оказалось, что название это было уже забыто, но на предполагавшемся расстоянии, то есть верстах в 5 от Очакова, народ помнил иарскую палатку. Невероятно ли в высшей степени, что это то самое место, где Карл велел разбить палатку, полученную в дар от султана?

Невдалеке от этого места мы остановились, чтобы расспросить о нем в первой деревне Кугуруг [Куцуруб]. Но жители не могли ничего сказать и мы решились поискать его сами. Мы нашли четыре низенькие земляные вала, которые образуют почти квадрат в 80 шагов [56,9 км], с отверстием или входом в середине каждой стороны. Местами земля раскопана: видно, что тут в позднейшее время доискивались остатков старины. Можно предполагать, что в этом четырехугольнике находилась «Царская палатка», когда шведы 13-15 июля в последний раз стояли лагерем близ Очакова. Расстояние приблизительно соответствует приведенному. Годной для питья воды здесь нет и теперь, так как Днепровский лиман недалеко отсюда сливается с морем. Наконец, догадка эта не опровергается и тем, что Карл держался поодаль от проезжей дороги: если бы этого названия и заслуживал поселок, который нас привел сюда, и если бы он уже существовал в турецкое время, во всяком случай место лагеря приходилось бы на расстоянии 1/6 версты от этой дороги.

Итак, вот где шведы вторично испытали недоброжелательство паши. Когда король велел перевезти в Очаков больных, которых /595/ число с каждым днем увеличивалось, то турецкий сановник не отказал в том, но принял несчастных так дурно, что они сами возвратились, как могли, к своим соотечественникам. По уверению шведов, это и побудило Карла приказать 15 числа пуститься снова в путь и на 20 верст подняться опять в степь. Мотрей, напротив, рассказывает, что паша снабдил короля проводниками, лошадьми, повозками и всем нужным на остальные 200-300 верст до Паланки, местечка при Днестре, где бендерский сераскир таким же образом позаботился о их дальнейшем походе. 
Но сомнения наши насчет отысканного места с каждым шагом увеличивались. Тотчас после описанных валов начинаются в бесчисленном множестве другие, продолжающиеся до самых ворот Очакова. Правда, они, судя по виду, возникли большей частью позднее и насыпаны русскими при осаде Очакова. Тем не менее, все эти валы сбивали нас с толку и слово, которого мы искали, оставалось для нас неразгаданным.

\section{VII}

О нынешнем Очакове нечего распространяться, но тем более можно бы рассказать о кровавых его воспоминаниях. Основанный в XV столетии крымским ханом Менгли-Гиреем, Очу-Кале или Джиан-крименда имел в XVII веке, когда Боплан посетил этот край, не более 2000 жителей, но был сильно укреплен и, вместе с лежавшим против него Кинбурном, заграждал вход в Днепр, где обыкновенно стояли турецкия галеры. В конце сказанного столетия город этот был сожжен и разграблен тем самым Мазепой, который впоследствии сделался другом Карла XII и вместе с ним гостеприимно принят был в Турции. При Мотрее, который не раз бывал в Очакове, крепость и стены его были в хорошем положении. В 1737 году он в первый раз был взят русскими, а через 51 год Потемкин, после шестимесячной осады, одержал тут знаменитую победу, которая, вместе с торжеством Суворова при Измаиле, решила судьбу всего этого края.

Не зная этого, трудно угадать посетителю Очакова, как некогда важен и замечателен был этот город. Летописи Одессы, которая с самого начала своего существования возвысилась торговлей, решать вопрос, почему Очаков уже не мог более поправиться. Небольшое (первоначально турецкое) укрепление полощет свою подошву частью в Днепре, частью в Черном море и смотрит очень значительно. Но сам город, построенный выше, состоит из низеньких выбеленных домиков с соломенными крышами, разбросанных /596/ где и как попало. Новые развалины можно видеть на каждом шагу, но от старинных и древних не осталось и следа.

Мы пробыли в Очакове часа два, но никак не могли согласиться в цене за некоторые ольвийские и шведские монеты, которые продавались вместе с турецкими гирями, - точно так же, как фурман наш не мог сторговать ведра воды, которым он хотел освежить своих лошадей. Что касается до древностей, то мы не нашли ничего замечательного, кроме поврежденной турецкой надписи на мраморе и четырехугольного пьедестала из того же камня: надпись была у лестницы, а пьедестал у ворот станции; мрамор был синеватый, в роде того, что привозится из Мальты. Но о греках ни малейшего воспоминания, -обстоятельство, которое само по себе уже, если бы и не было никаких других доказательств, могло бы опровергнуть нелепое мнение прежних археологов, будто Очаков стоит на месте древней Ольвии. Правда, что во времена Дия-Златоуста здесь было селение, но только не греческое, а сарматское, именно крепость Алектора.

Из Очакова почтовая дорога идет на север к Янчокраку, где мы уже были, ехав из Одессы. По этому направлению пошли шведы, выступив из последнего лагеря при Очакове, чтобы обойти лиман Березани, может быть, по тому самому мосту, по которому и мы проехали прежде. Теперь, напротив, мы взяли путь по узенькой полосе земли, которая, имея в длину верст 5 или 6, вдается в устье реки. Влево у нас было открытое море, вправо последний приток Березани, скромный Пекум [Бейкуш], которому, как и большей части степных рек, приходится, несмотря на большое устье его, почти круглый год мучиться жаждой или разве только смачивать губы. В его долине столпилось несколько дач и окружающая их зелень придает много живости виду.

Как я уже сказал, Березань не имеет пересыпи; место того устья ее охраняется двумя длинными косами, которые как клыки идут, сближаясь, от обеих челюстей реки. Еще Боплан, около половины XVII века, заметил, что Березанский лиман, по своему узкому, но довольно глубокому устью и по высоким берегам своим, мог бы служить удобной гаванью для галер и других мелких судов. Но, как известно, на Черном море всего только два острова, хотя Идриси и другие арабские географы и насчитывают их до семи. Оба эти острова представляют характер голой степной 
природы и заключают в себе каждый менее одной квадратной версты. До одного из них нет и двух верст расстояния от берега; он лежит против самого устья Березани, с которою носит одно имя, и вы легко можете вообразить, как жадно я глядел издали на эту недоступную редкость: две версты какая малость сухим путем! Но /597/ на море, а особливо на этом море, надобно заблаговременно приготовить средства к такому путешествию. Я чрезвычайно жалел, что обстоятельства не позволили нам осмотреть и исследовать этот предмет спора между археологами, тем более, что и наше маленькое общество не могло согласиться в мнениях насчет загадочного острова.

Мы переправились благополучно, хотя не без опасности, на другой берег реки, при вздохах и благословениях нашего испуганного фурмана. Рулем на лодке управлял еврей и был очень искусен в своем деле. Чем только не занимаются здесь дети Израиля? По ту сторону Березани проехали мы справа деревню Аджиан [Аджияск], - татарское имя, ясно напоминающее народ Axiacae и реку Axiaces, которым древние назначили место недалеко оттуда. Потом степь почти необитаема до Телигула; не видно ни одного обработанного клочка земли, только по морскому берегу встречаются на равном расстоянии одни от других, маленькие домики для карантинной и таможенной стражи, которая наблюдает, чтобы не приставали суда с чумой или контрабандой. Под ее же надзором состоят рыбаки с их лодками, которые иначе могли бы поддерживать торг контрабандой. Так называемый кордон тянется вдоль всего черноморского берега до города Рени при впадении Прута в Дунай или до турецко-австрийской границы.

В этот раз мы проехали по Телигульской пересыпи вдоль самого моря, тогда как в первый проезд держались ближе к лиману. Телигул есть одно из немногих мест, поименованных в маршруте шведов на Бендеры, почему я, при описании нашей археологической прогулки в Коблевку, и выразил предположение, что тамошние валы, может быть, насыпаны ими. Теперь я уверился в этом еще более, видя из указания пройденных шведами расстояний, что они около того места действительно имели привал 16 июля. Может быть валы окружали просторную, богатую палатку короля, ибо известно, что Карл, где бы он ни находился, любил ограждать себя какимнибудь укреплением, и что он обыкновенно посылал людей вперед для устройства лагеря. Огороженное пространство здесь почти того же размера, как то, которое, по нашему предположению, «Царская палатка» занимала близ Очакова. Правда, валы здесь повыше, но зато их никто не раскапывал; сверх того у них нет отверстий посередине, а есть только (если не ошибаюсь) вход в одном углу; но и то и другое могло быть сделано из осторожности: эти края и все пространство от Очакова почти до Бендер не только во время шведского похода и Мотрея, но еще в исходе прошлого столетия представляли совершенную глушь, -обстоятельство, которым также объясняется, почему нет никаких преданий об этом единственном в степи памятнике. /598/

Шведы перешли Телигул 17 июля и рассказывают, что на месте перехода «озеро» было очень мелко, усеяно островами и наполнено камышем, и что река того же имени, «протекающая через озеро», ниже его тотчас впадает в море. В этом описании, как мне кажется, легко узнать лиман и пересыпь или так называемые плавни. Но если бы кто-либо нашел, что этим опровергается мое замечание о существовании пересыпи еще в IV веке, то я привел бы известное обстоятельство, что еще и в наше время вода прорывается иногда через пересып, что вероятно случилось и на этом месте в 1709 г. По крайней мере, писавший гораздо ранее Боплан говорит положительно, что Телигул тогда уже не имел устья, отделяясь от моря «естественной плотиной».

Здесь я до времени расстанусь с бегущими шведами. Хотя они далее шли по берегу Черного моря, однако же не упомянуто, заходили ли они в месторождение столь цветущей ныне Одессы. Мы теперь не едем, а летим туда, отпустив в Сычевке нашего фурмана с его тройкой, так как живущий поблизости помещик предложил нам свою четверку отличных рысаков и дорожный экипаж, устроенный с удивительной изобретательностью.

Через несколько дней отправился я в Бессарабию, потом ездил к Дунаю и, наконец, в Варницу, место лагеря при Бендерах. Поэтому я бы мог уже в настоящем письме последовать за шведами до 
пункта, где они остановились; но лучше я перерву свой рассказ об описанных здесь местах, составляющих как бы особый отдел.

Igor Sapozhnykov

\section{Lagus and his letters about the journey of 1851 from Odessa to Olvia and in the footsteps of the army of Charles XII}

Abstract: The article is devoted to the publication of the forgotten «Letters from the Black Sea», devoted to the description of the trip of 1851 from Odessa to Olbia (Appendix). During it, archeological excavations and a survey of the camps of the Swedish army were carried out, which after the defeat near Poltava retreated under the leadership of King Charles XII from the Southern Bug to Bender. The author of the letters is Jakob Johann Wilhelm Lagus (18211909) - doctor of Philosophy, Professor and Rector of the University. He spent most of his life studying Eastern and Greek linguistics, history and numismatics in Finland, and after the trip he wrote the book «Charles XII in Southern Russia» (latest edition in 2018). Professors of Richelieu Lyceum, specialists in historical geography P. Becker and F. Brun took part in the trip.

The article describes the biography of V. Lagus and his contribution to the study of the past of the North-Western Black Sea coast. Particular attention is paid to the trip, which can be considered as one of the first attempts to conduct a comprehensive archaeological and historical expedition in the region. The author reconstructed its route and chronology, paying special attention to the descriptions of archeological monuments and the remains of camps on the way of the Swedish troops. Drawing on known and unpublished maps, as well as data from his own observations and explorations, the author concluded that the dating of a number of earthen fortifications inspected by V. Lagus in 1709 was not confirmed: Petukhivka II settlement and two earthen fortified camps Chortovate and Koblevo date to Roman times. Rectangular camp between the Russian spit and the mouth of the Hetman's valley Swedes probably used, as Swedish coins from the 1630s and 1650s were found there, but it should be found and explored on site.

Keywords: V. Lagus, North-Western Black Sea Coast, Odessa, Olbia, Charles XII, Swedish retreat, Russian Spit, Wallachian Spit, Ochakiv, Tiligul, Roman military camps

\section{Список скорочень}

$\mathrm{AB}$ - Археологические вести. Санкт-Петербург

АДІУ - Археологія і давня історія України, Київ

АН - Академія наук

ЗНТШ - Записки наукового товариства ім. Шевченка, Львів

ЗООИД - Записки Одесского общества истории и древностей

МПС - Министерство путей сообщения

OTIC - Одеське товариство історії і старожитностей

РНБ - Російська національна бібліотека, Санкт-Петербург

РДАДА - Російський державний архів давніх актів, Москва

ТОСК - Труды Одесского статистического комитета 
\&) Старожитності Лукомор'я œ 2021 - № 4 (7)

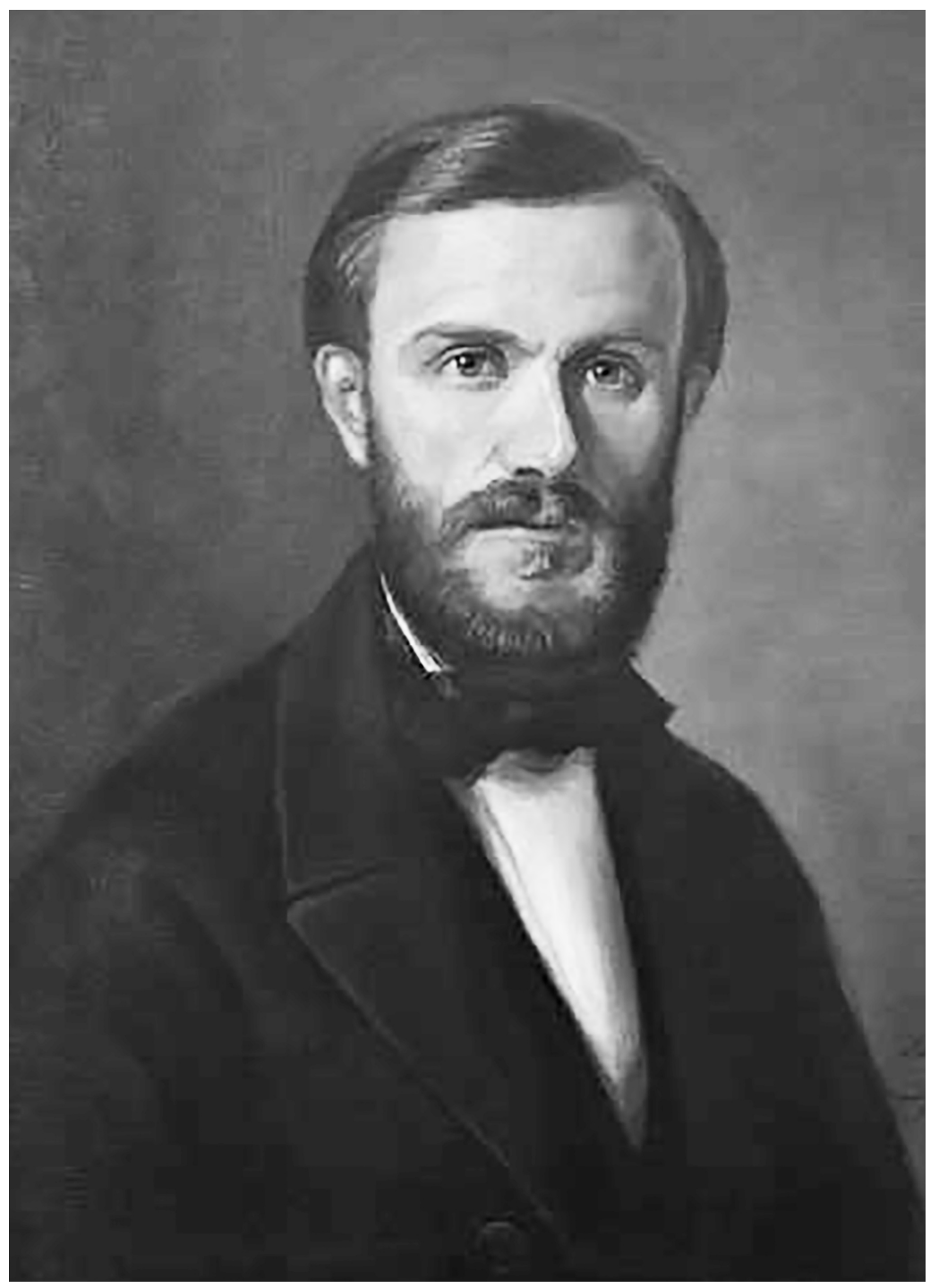

Рис. 1. Якоб Йохан Вільгельм Лагус (з портрета роботи Іди Сільфверберг). 


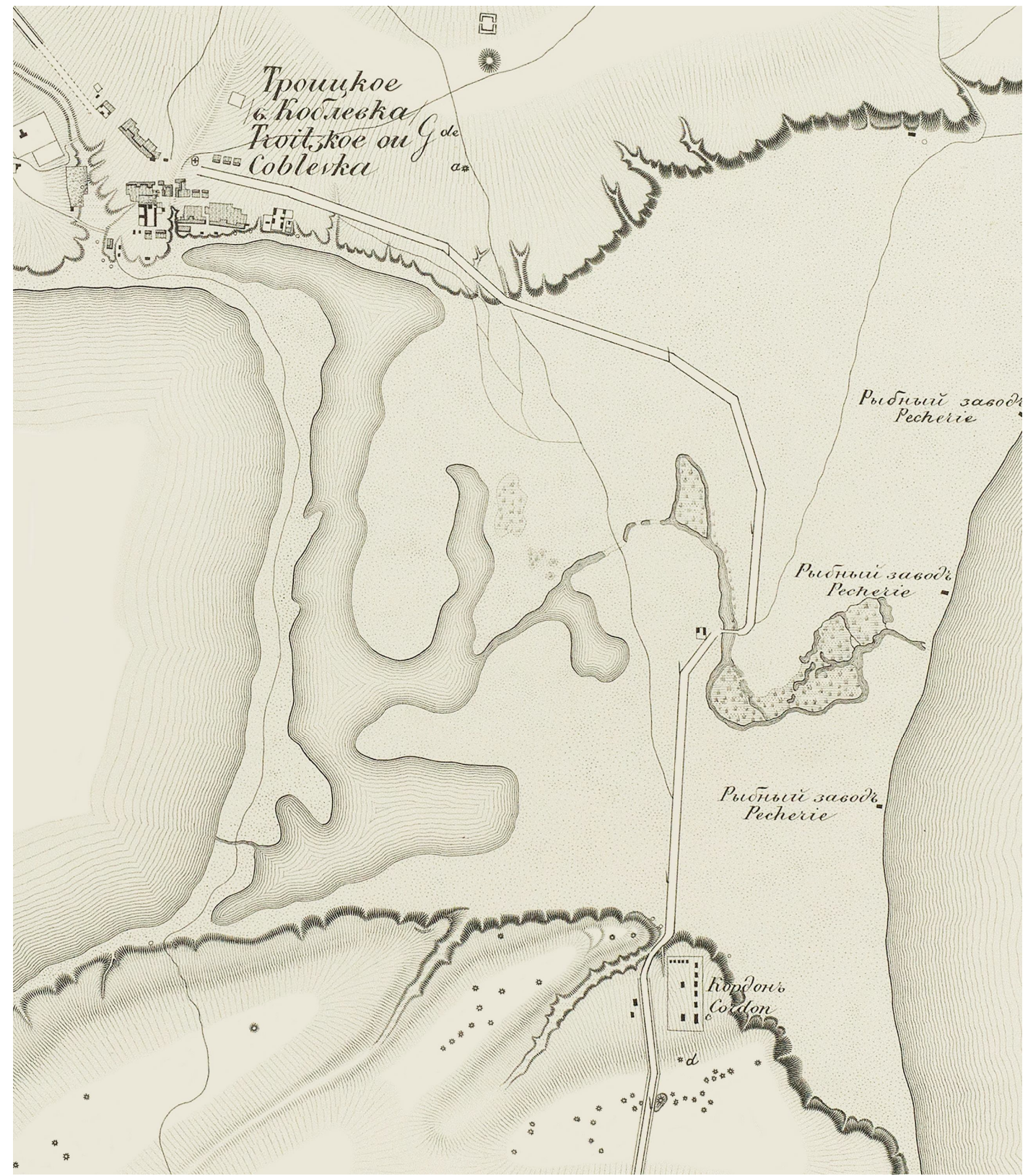

Рис. 2. Пониззя Тилігульського лиману в 1848 р.

(план А. Олексійова; $\phi-т)$. 


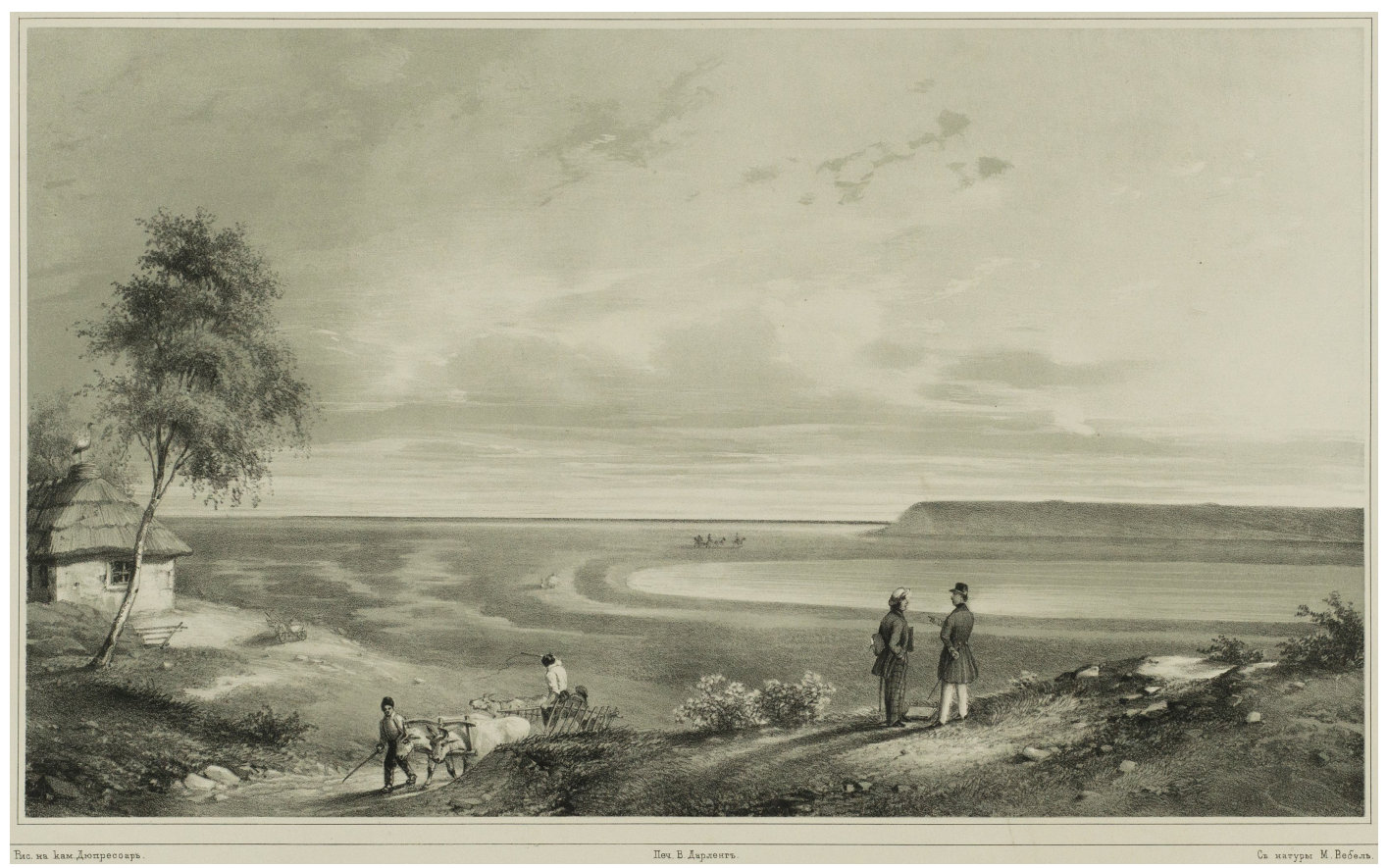

Рис. 3. Вигляд пересипу Тилігульського лиману з лівого берега у 1848 р.

(гравюра з малюнка М. Вебеля).

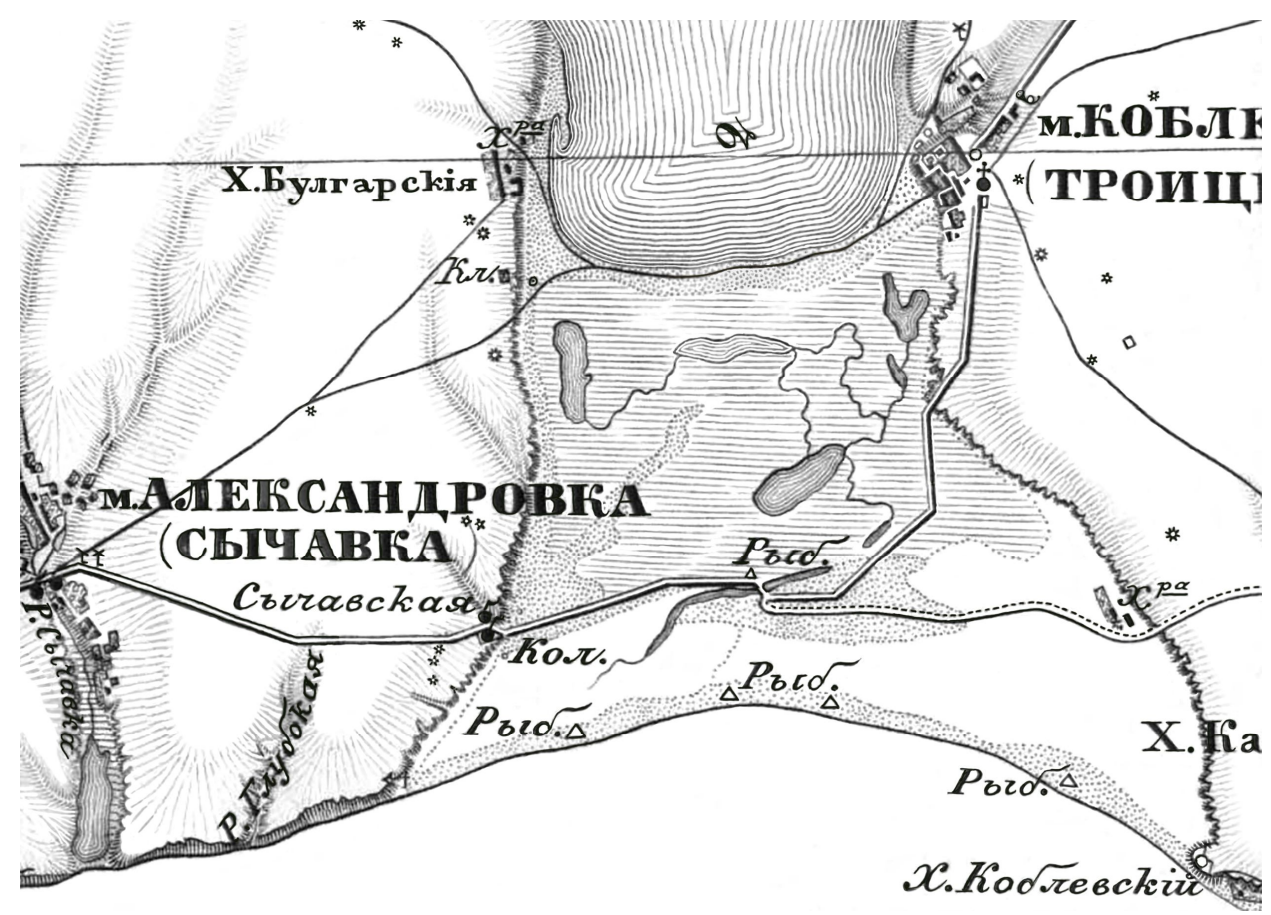

Рис. 4. Пересип Тилігульського лиману на «триверстовій» карті (Початок 1850-х рр.; аркуш XXX-9; ф-т). 


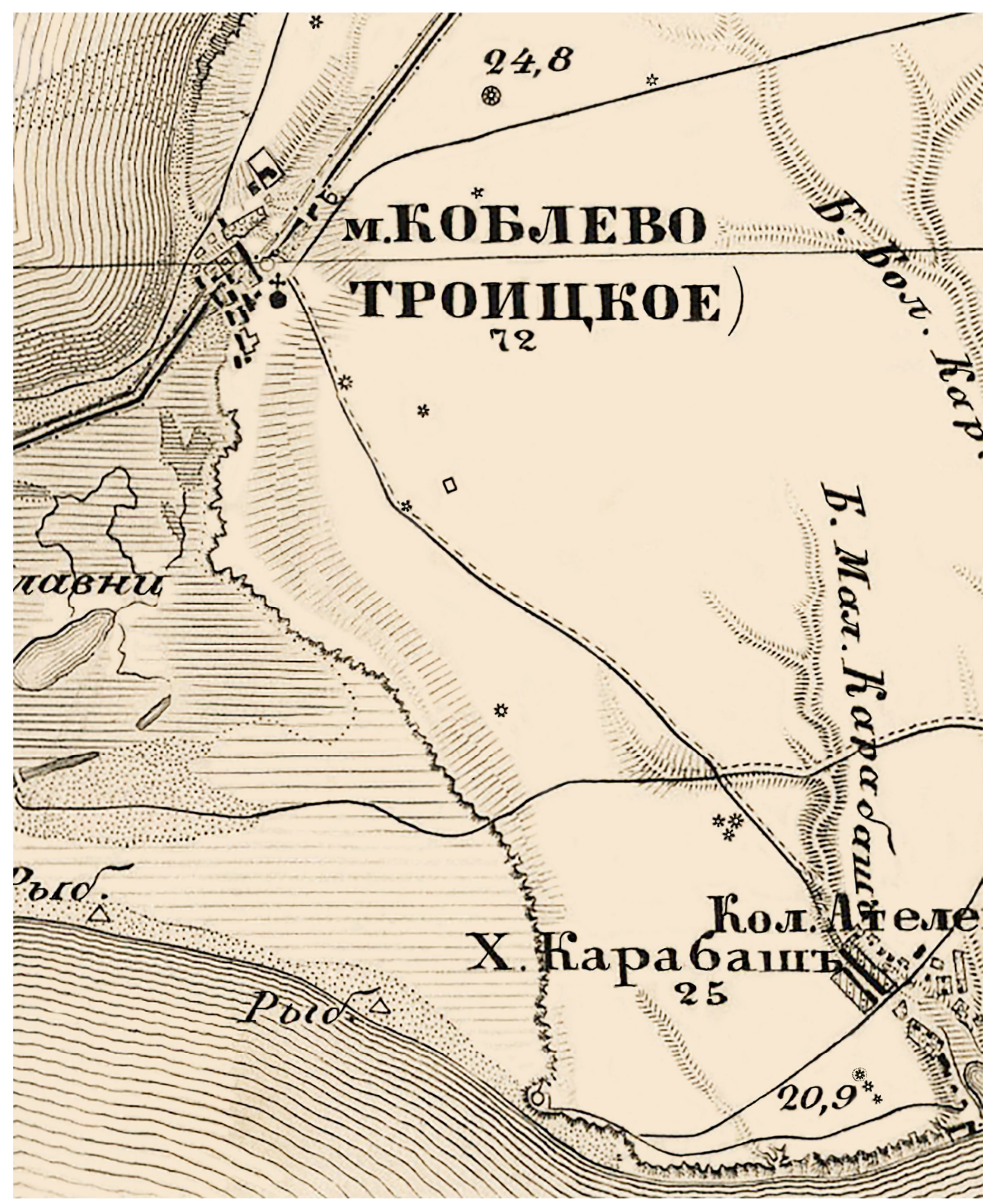

Рис. 5. Частина пересипу і лівого берега Тилігульського лиману на «триверстовій» карті (1869-х рр.; аркуш XXX-9; ф-т). 


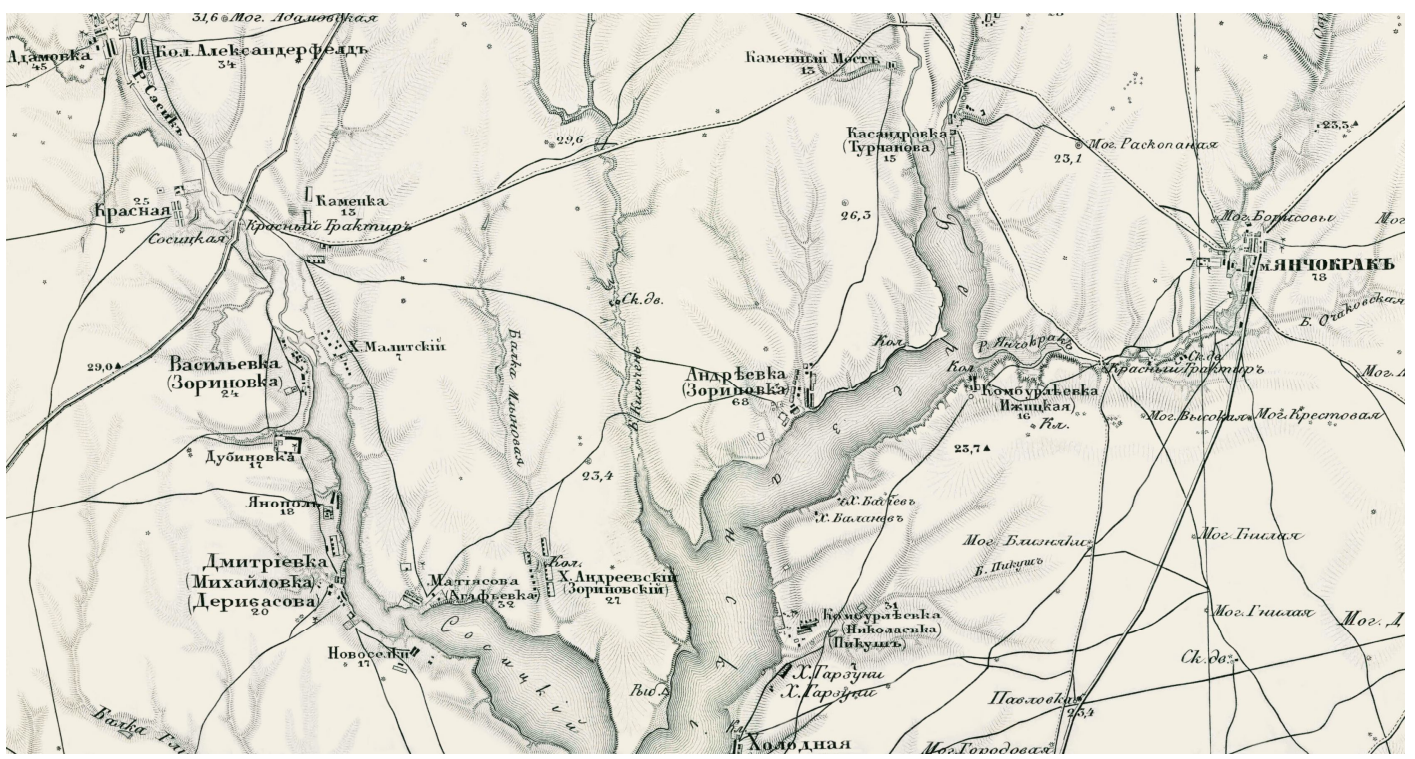

Рис. 6. Верхів'я Березансько-Сосицького лиману на «триверстовій» карті (1869 р.; аркуш XXX-10; $\phi-т)$.

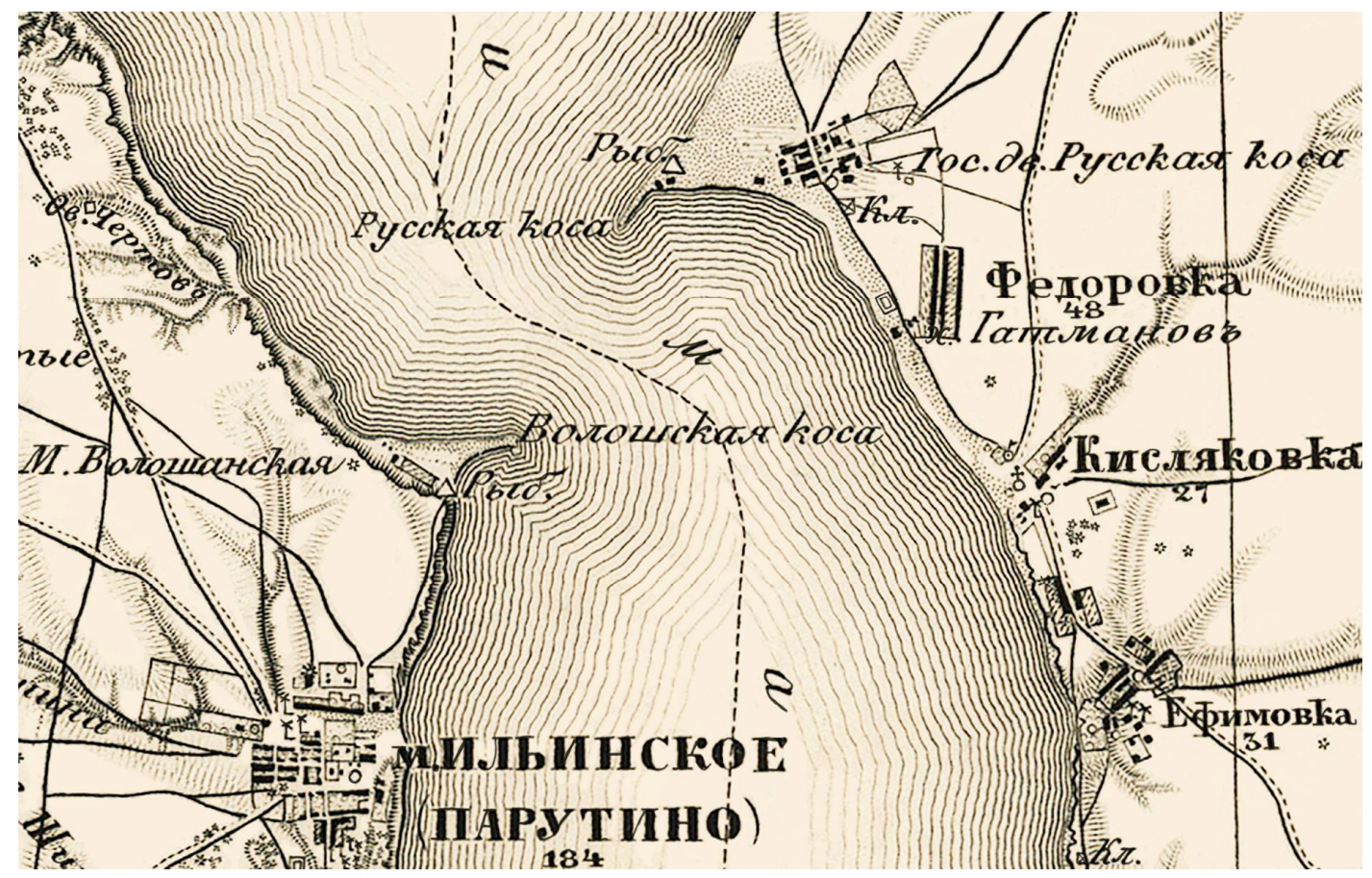

Рис. 7. Район Волошанської і Руської кос на «триверстовій» карті (1869 р.; аркуш XXX-10; $\phi-т)$. 


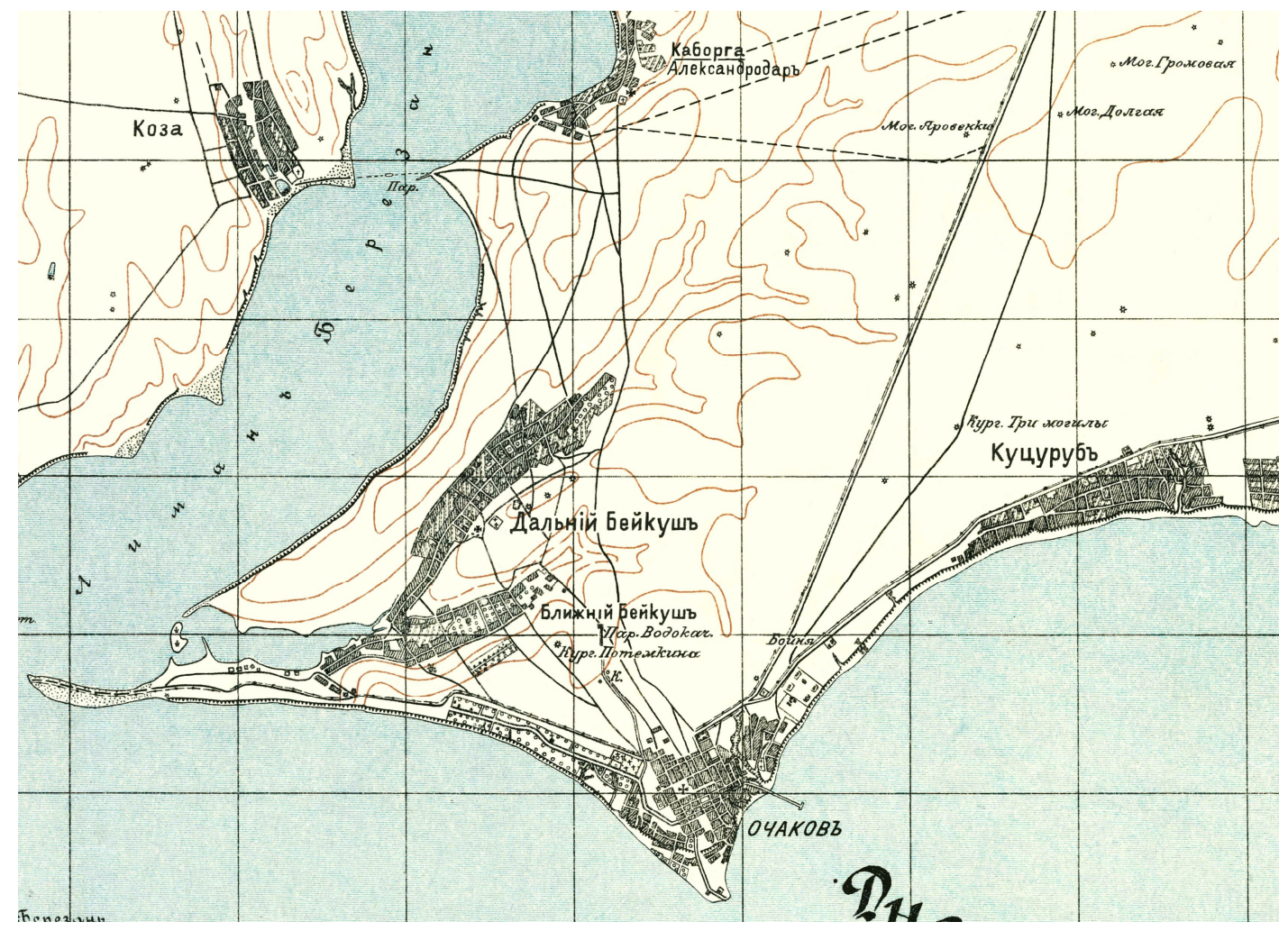

Рис. 8. Район Очакова на «двохверстовій» карті (1907-1908 р.; аркуш XLV-32; ф-т). 


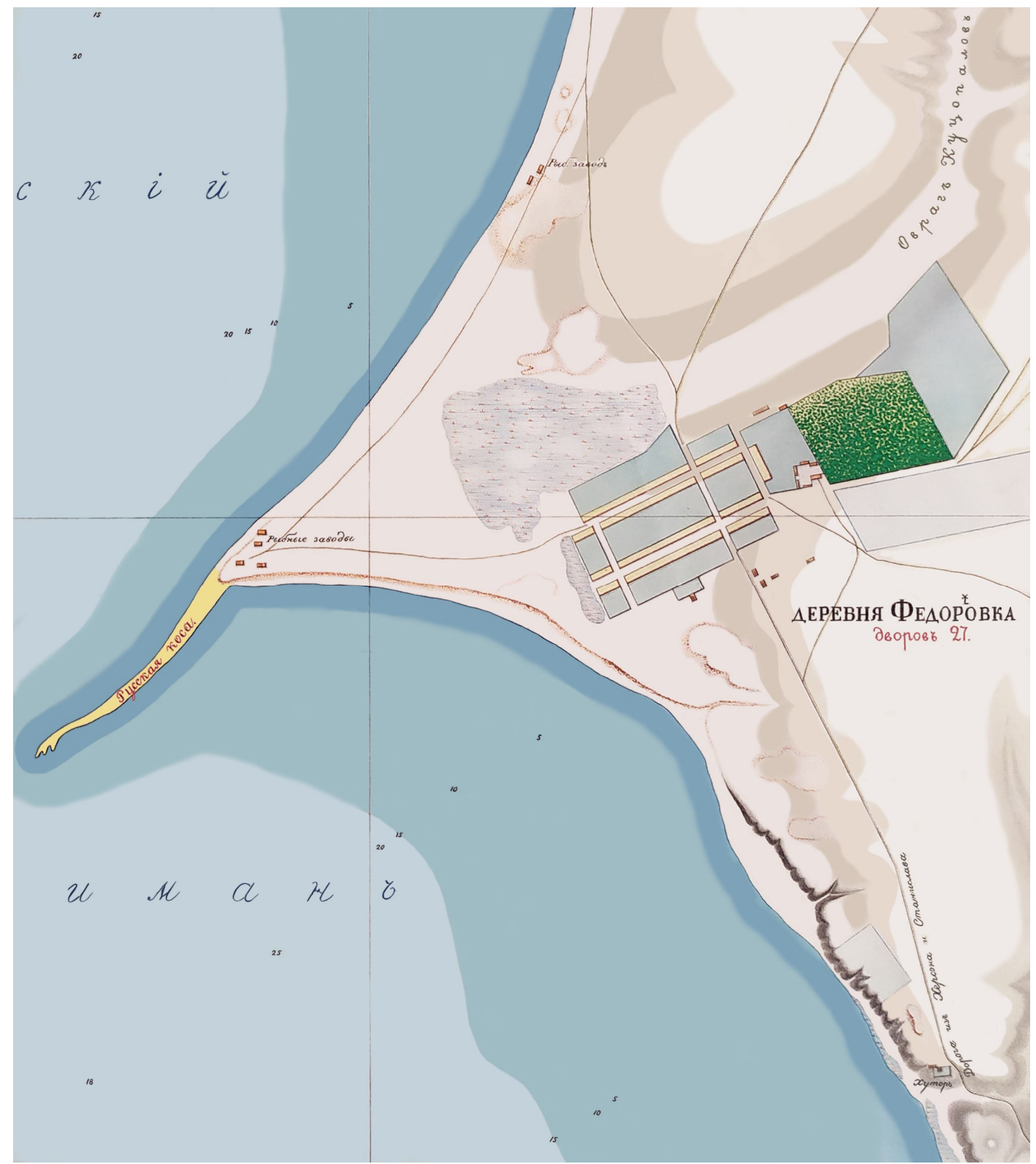

Рис. 9. Руська коса на плані А.П. Чиркова 1863 р.

(зберігається в ОАМ). 


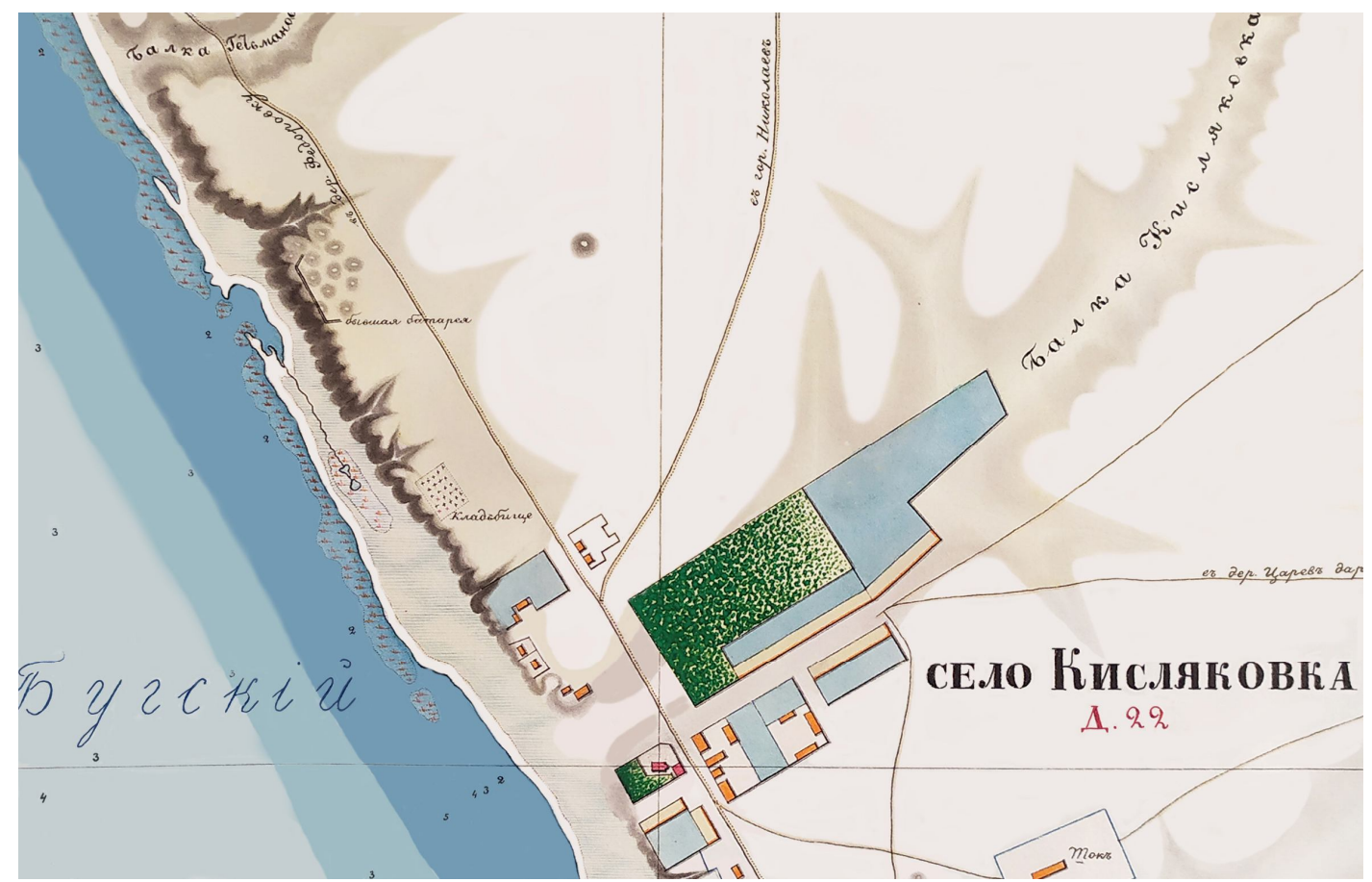

Рис. 10. Район с. Кисляківки на плані А.П. Чиркова 1863 р. (зберігається в ОАМ). 


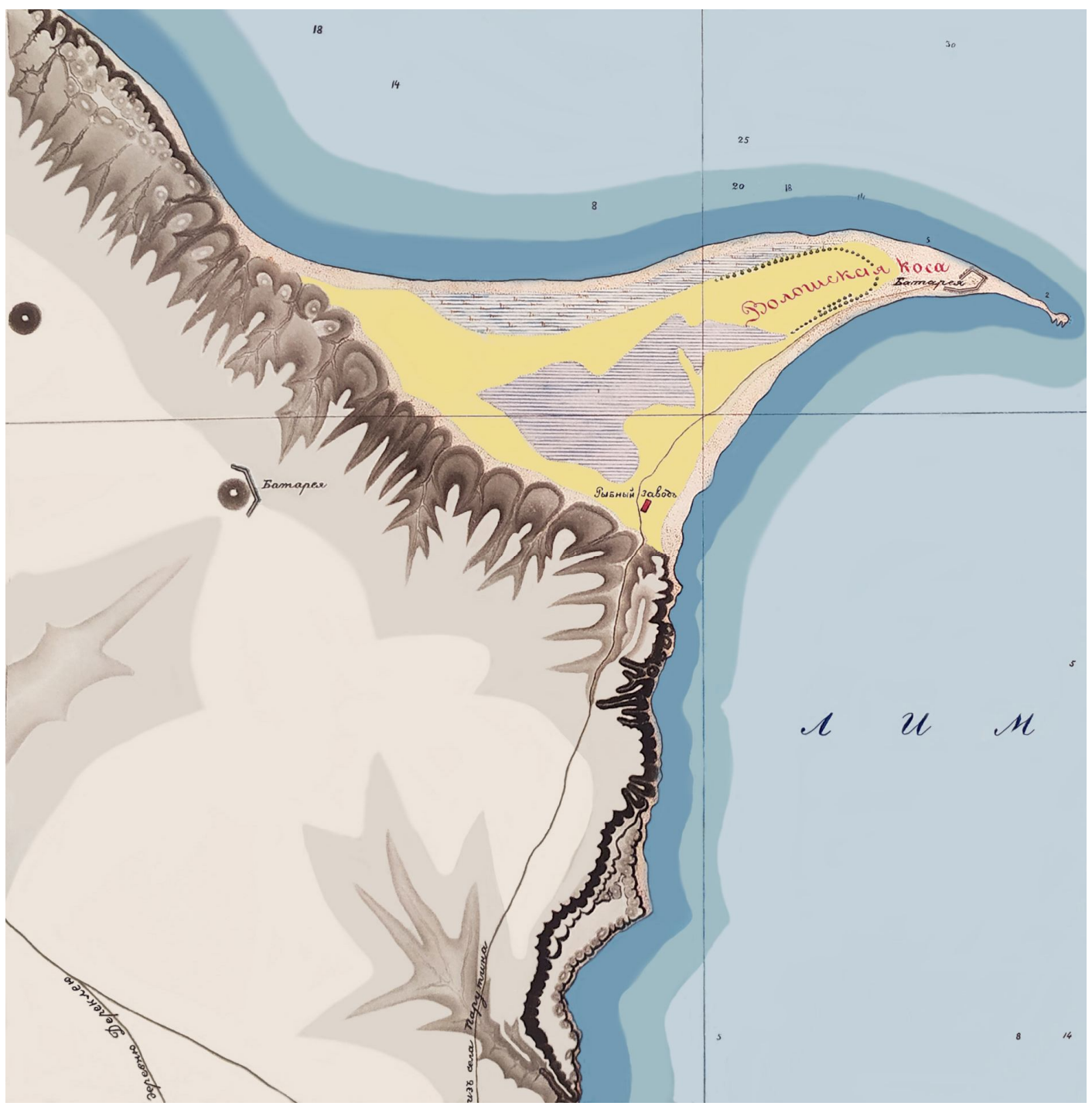

Рис. 11. Волоська коса на плані А.П. Чиркова 1863 р. (зберігається в ОАМ). 
\&) Старожитності Лукомор'я œ

2021 - № 4 (7)

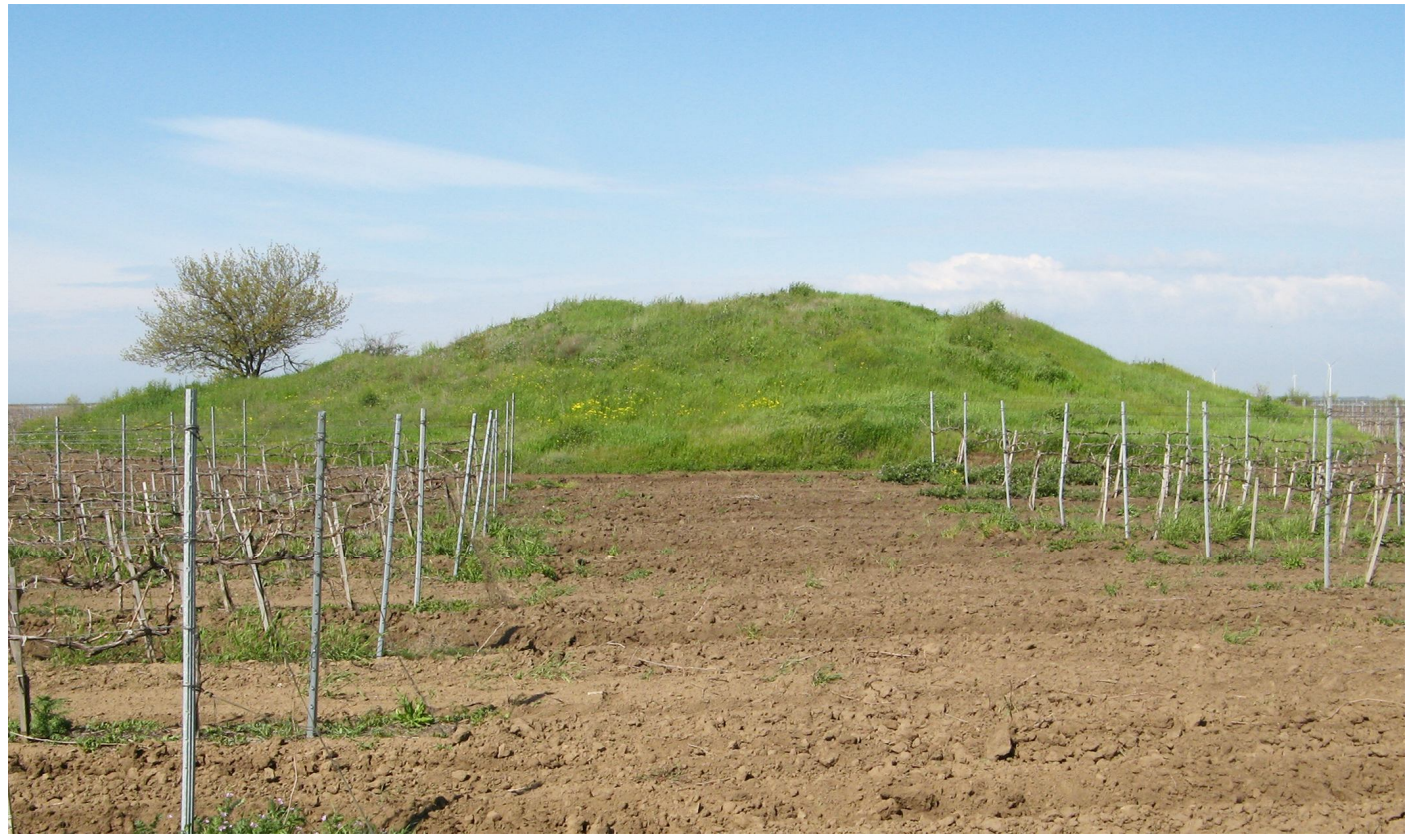

Рис. 12. Курган Вільгельма Лагуса поблизу с. Коблева у 2021 р. (вигляд зі сходу; фотознімок I. Сапожникова) 